\title{
Best channels of academia-industry interaction for long-term benefit
}

\author{
Dr. Claudia De Fuentes ${ }^{1}$ \\ Dr. Gabriela Dutrénit ${ }^{2}$
}

\begin{abstract}
Interactions between public research organizations and industry can be conceptualized as having three main stages: drivers of interaction, channels of interaction, and the perceived benefits from collaboration. Both of the agents differ in terms of the incentives they have to collaborate and the behaviors they adopt during the collaboration process. Following a three-stage model based on Crépon, Duguet, and Mairesse (1998), this paper discusses the impact of drivers of collaboration on channels of interaction, and the impact of these channels on the perceived benefits by researchers and firms. The methodology also allows firm-level benefits from interaction to be connected with researchers' characteristics via the analysis of four common channels of interaction for firms and researchers. The study is based on original data collected through two surveys, carried out in Mexico during 2008, of R\&D and product-development managers of firms and of academic researchers. Our results show that all channels of interaction play an important role in determining benefits; however, they differ in terms of their impact on short-or long-term benefits for firms. The channels related to joint and contract R\&D, property rights, and human resources are the best, as they have a higher impact on long-term benefits for firms. Policy implications derived from this study focus on specific actions that enhance those researchers' characteristics related to the best channels for fostering long-term benefits for firms.
\end{abstract}

Keywords: university-industry interactions; collaboration drivers; channels of interaction; benefits; innovation policy; developing countries; Mexico.

\section{Introduction}

The role of universities and public research centers (centers), hereafter public research organizations (PRO), ${ }^{3}$ is evolving, from the formation of human resources and the generation of knowledge to the more specific focus of solving problems and attending to social needs (Etzkowitz and Leydesdorff, 2000; Göransson, et al., 2009). There is plenty of evidence that PRO can make important contributions to increasing the economic performance of firms and attending to social needs in both developed and developing

\footnotetext{
${ }^{1}$ Corresponding author. CIRCLE, Centre for Innovation, Research and Competence in the Learning Economy and Assistant professor at Saint Mary's University, Sobey School of Business. Telephone (902) 420 4056. Fax (902) 420 5119. claudia.defuentes@ smu.ca (www.smu.ca/academic/sobey. Sobey Building, Office \# 217 Saint Mary's University 903 Robie Street Halifax, Nova Scotia B3H 3C3).

2 Professor of the postgradute program in Economics and Management of Innovation, Universidad Autónoma Metropolitana-Xochimilco. Fax (5255) 5483 7235. gdutrenit@laneta.apc.org (Mexico City, Calzada del Hueso 1100, col. Villa Quietud Coyoacán, CP 04960).

${ }^{3}$ In this paper we use PRO to refer to universities and public research centers. We are aware that these organizations may differ in relation to their role in the National System of Innovation and the knowledge production process, as well as in other aspects; however, in the Mexican case, researchers working at these two types of organizations confront a set of common incentives that contribute to explaining why and how they tend to interact.
} 
countries (Vessuri, 1998; Casas, et al., 2000; Cohen, et al., 2002; Arocena and Sutz, 2005; Albuquerque, et al., 2008; Bekkers and Bodas Freitas, 2008; Maculan and Carvalho, 2009; Perkmann and Walsh, 2009; Cassiman, et al., 2010).

Interactions between PRO and industry (PRO-I) are seen as one of the key elements of the National System of Innovation (NSI). However, it is broadly recognized that PRO have evolved at a different pace and with only limited interaction with other agents in developing countries (Cimoli, 2000; Lall and Pietrobelli, 2002; Cassiolato, et al., 2003; Muchie, et al., 2003; Lorentzen, 2009; Dutrénit, et al. 2010b). On the one hand, firms do not see PRO as a primary source of knowledge and a partner for innovation activities; on the other, academic researchers are more likely to be engaged in basic research than in technology-development projects. Thus the promotion of stronger PRO-I interactions can play an important role in consolidating NSI in developing countries, as such initiatives can promote virtuous circles in the production and diffusion of knowledge.

There is an increasing literature regarding PRO-I interactions that approaches several relevant issues, including drivers, channels of interaction, and perceived benefits. The authors focus either on PRO (e.g., Melin, 2000; Bozeman and Corley, 2004; Eun, et al. 2006; D'Este and Patel, 2007; Boardman and Ponomariov, 2009; Göransson, et al. 2009; D'Este and Perkmann, 2010; Wigren et al, 2011) or on the perspective of firms (e.g., Laursen and Salter, 2004; Hanel and St-Pierre, 2006; Fontana, et al., 2006; Mathews and Mei-Chih, 2007; Jensen et al. 2007; Ayadi, et al., 2009); still other studies have analysed PRO-I interactions from both perspectives (Carayol, 2004; Bekkers and Bodas Freitas, 2008; Intarakumnerd and Schiller, 2009; Dutrénit, et al., 2010; Arza and Vazquez, 2010; Fernandes, et al., 2010; Orozco and Ruíz, 2010). Three stages of the linking process can be identified: drivers of interaction, channels of interaction, and the perceived benefits. Authors usually focus on one of these stages, and sometimes they address the links between certain channels (mostly joint $R \& D$ ) and any benefits. By contrast, this paper analyzes both agents - PRO and firms - and aims to perform a systematic analysis of the nature of PRO-I interactions across the three stages of the linking process. We are particularly interested in connecting the benefits firms derive from interaction with researchers characteristics by analyzing the use of four channels of interaction by both agents. Hence, this analysis provides the basis for identifying the specific researchers characteristics that are important for fostering those channels that bring long-term benefits for firms - i.e., the best channels of PRO-I interaction.

The conceptualization of three stages of the linking process is relevant for innovation policy, particularly for those programs oriented toward fostering PRO-I interactions. Such programs have rarely recognized that the degree to which agents are engaged in collaboration differs according to their drivers (Dutrenit, et al., 2006). Rather they have largely looked at increasing knowledge flows from PRO to industry through joint and contract research and patenting and have not acknowledged other channels that can foster stronger interactions, such as human resources mobility, training, and the sharing of tacit and codified knowledge. Sá and Litwin (2011) reviewed the policy mix in Canada to foster PRO-I collaboration and found that those programs provide incentives for interaction by increasing networking and collaborative research projects. However, these 
programs do not recognize that each agent has different reasons for interacting. D'Este and Perkmann (2010) found that researchers in the UK have different motivations to collaborate, and they suggest the implementation of other types of incentives to collaborate which are based on those motivations. Thus, one of the challenges for policy makers is to create incentives other than funding to improve PRO-I interaction (D'Este and Perkmann, 2010; Sá and Litwin, 2011; Leisyte, 2011). In addition, channels of interaction differ in terms of their relative effectiveness on the benefits obtained by both agents (Arza, 2010). This should also be taken into account by policymakers to ensure policy effectiveness. Thus, understanding the connection between firm-level benefits from interaction with researcher characteristics through four channels of interaction may help to identify specific policies which will foster sustainable long-term benefits and which may in turn improve the innovation performance of firms.

Concerning innovation policy in the Mexican case, one of the key agents of NSI is the National Council on Science and Technology (CONACYT), which was created in 1970 and has played an active role in designing and implementing that policy. Promoting PROI interactions has been a goal over the last decade; several programs designed to foster the innovation of firms include interactions as one of their objectives and have contributed to increased interactions or at least the perception of their importance. Probably the most effective program has been the fiscal incentives for R\&D (Dutrénit, et al., 2010b). From the PRO side, the incentives structure is dominated by the National Researchers System, which was created in 1984. This program provides both pecuniary stimulus (a monthly compensation) and non-pecuniary stimulus (status and recognition) to researchers according to their productivity and the quality of their research, and constitutes an important incentive for publishing papers in ISI journals. Thus any program to foster PRO-I interactions in Mexico is mediated in some way by the National Researchers System must to take that into account in its design.

In this context, this study is based on original micro data collected through two surveys, which analyzed PRO-I interactions carried out in Mexico during 2008. ${ }^{4}$ One focuses on $\mathrm{R} \& \mathrm{D}$ and product-development managers of firms and the other on academic researchers, either from universities or centers. Based on the methodology which employs the three stages proposed by Crépon, et al. (1998), ${ }^{5}$ we build two models, one for researchers and one for firms, to identify the effect of drivers to collaborate on channels of interaction and the effect of these channels on the perceived benefits of interaction. This analysis provides the basis for connecting the benefits firms derive from interaction with researchers characteristics.

The remainder of this paper is divided into five sections. The second section reviews different bodies of literature that address the issues discussed here. Section three

\footnotetext{
${ }^{4}$ This study is part of an international research project titled "Interactions between universities and firms: searching for paths to support the changing role of universities in the South", sponsored by IDRC (Canada) and developed under the umbrella of the Catching-up project. A survey was conducted in most of the countries using what was called the Roks researcher questionnaire and the Roks firm questionnaire.

${ }^{5}$ Crépon, et al. (1998) analyzed the links between research investment, innovation, and productivity at the firm level. They built a structural model that analyzes productivity by innovation output and innovation output by research investment.
} 
describes the strategy for data gathering and the methodology used. Section four presents and discusses the empirical evidence, and section five presents our conclusions.

\section{Conceptual framework: interactions between PRO and industry}

This section seeks to present a review of the literature that analyzes PRO-I interactions at each of the three stages of the linking process.

\subsection{Stage 1: Why do PRO and firms engage in collaboration? The drivers of collaboration}

It is widely recognized that PRO-I interactions represent an important factor for innovation and technology development (Cohen, et al., 2002). Some authors argue that the nature of interactions changes as the country develops, as they reflect a co-evolution of factors which depend on the context, incentives, and agents' characteristics, particularly their absorptive capacities and embedded culture (Mowery and Sampat, 2005; Albuquerque, et al., 2008). Following international trends, recent innovation policy in developing countries has focused on fostering PRO-I interactions by reproducing programs initially designed for developed countries. It does not clearly recognize either the differences in the initial conditions or that each agent responds to different incentives - academic researchers function within an academic framework, while firms depend on business reasoning. In fact, PRO and firms collaborate for different reasons; for instance, PRO are interested in acquiring new sources of funding and ideas for future research, sometimes in order to publish papers (Meyer-Krahmer and Schmoch, 1998; Lee, 2000; Welsh, et al., 2008; Perkmann and Walsh, 2009; D'Este and Perkmann, 2010), while firms are interested in identifying potential employees and accessing sources of knowledge which can lead to industrial applications (Adams, et al., 2003; Arvanitis, et al., 2008). In this sense, differences between the two perspectives are important for understanding the evolution of PRO-I interactions and designing specific policies to strengthen such interactions.

Studies analyzing the drivers of PRO-I interaction from the firm's perspective have found that structural, behavioral, geographical, and policy-related factors are the most important drivers of interaction. Structural factors include the firm's age (Eom and Lee, 2009; Giuliani and Arza, 2009), the firm's size (Cohen et al., 2002; Santoro and Chakrabarti, 2002; Hanel and St-Pierre, 2006), the sector and industrial environment (Laursen and Salter, 2004; Hanel and St-Pierre, 2006; Segarra-Blasco and Arauzo-Carod, 2008; Tether and Tajar, 2008), and whether the firm is part of a group (Tether and Tajar, 2008; Eom and Lee, 2009). Behavioral factors include the type of R\&D activities performed by the firms (Segarra-Blasco and Arauzo-Carod, 2008), the intensity of R\&D (Laursen and Salter, 2004; Eom and Lee, 2009; Torres, et al., 2011), and types of openness strategy to generate new ideas (Laursen and Salter, 2004; Dutrénit, et al., 2010a). Recent research focuses on the impact of the geographical proximity of firms and PRO, which should be connected with high-quality research performed at these PRO (Broström, 2010; Laursen, et al., 2011). Policy-related factors include business incubators (Nowak and Grantham, 2000; Etzkowitz, et al., 2005), the fostering of industrial innovative clusters (Sohn and 
Kenney, 2007), and the initiation of joint research projects. In addition, several authors have found that firms that invest highly in $R \& D$ are more prone to have higher absorptive capabilities to learn and interact with universities (Cohen, et al., 2002; Fontana, et al., 2006) and that they prefer to interact with high-quality universities (Laursen, et al., 2011).

From the perspective of academia, some studies have found that institutional and individual factors explain the likelihood of engagement in PRO-industry interactions. Institutional factors include institutional affiliation (researchers working in centers have more opportunities to connect than those working in universities (Boardman and Ponomariov, 2009)), the mission of the university (universities that emphasize entrepreneurship tend to collaborate more with firms than those that do not (Etzkowitz and Leydesdorff, 2000; Mowery and Sampat, 2005; Jain, et al., 2009)), previous experience in technology-transfer (D'Este and Patel, 2007), the scale of research resources and access to different sources of funding for research by the various departments (Lee, 1996; Schartinger, et al., 2002; Colyvas, et al., 2002; Bozeman and Gaughan, 2007), and the quality of research (Mansfield and Lee, 1996; Schartinger, et al., 2002). Individual factors include the gender and age of faculty members (Jensen, et al., 2008; Giuliani, et al., 2010; Arza and Vazquez, 2010; Wigren et al, 2011), previous experience in interaction (Bekkers and Bodas Freitas, 2010), the academic status of faculty members and their research fields (Friedman and Silverman, 2003; Bercovitz and Feldman, 2003; D'Este and Patel, 2007; Bekkers and Bodas Freitas, 2008; Jensen, et al., 2008; Boardman and Ponomariov, 2009; Rivera, et al., 2011; Wigren, 2011), the extent of academic collaboration (Boardman and Ponomariov, 2009; Dutrénit, et al., 2010a; Rivera, et al., 2011), faculty members' motivation (Jain, et al., 2009), and the faculty members' centrality in the network (Giuliani, et al., 2010).

Regarding regional proximity, Bishop, et al. (2011) and Laursen, et al., (2011) found that geographic proximity is an important determinant for firm-industry interaction; Broström (2010) confirms the importance of geographic proximity for fostering channels of interaction.

\subsection{Stage 2: Which are the main types of knowledge transfered through channels of interaction?}

Several studies focus on the core of the linking process - the interaction stage. Empirical evidence suggests that knowledge flows during PRO-I interaction through multiple channels, the most frequently recognized being: joint and contract R\&D; the mobility of human resources (students and academics); networking; information diffusion via journals, reports, conferences, and the internet; training and consultancy; property rights; incubators; and spinoffs. According to Bekkers and Bodas Freitas (2008), the relative importance of the various channels is similar among firms and academic researchers in Holland; however, academic researchers assign more importance to some channels than firms. In contrast, other authors argue that, from the industry perspective, joint $R \& D$ projects, human resources, networking, open science, and patenting are the most important channels (Narin, et al., 1997; Swann, 2002; Cohen, et al., 2002), while from the 
PRO perspective, the most important ones they are joint and contract R\&D projects, meetings and conferences, the mobility of human resources, training and consultancy, and the creation of new physical facilities (Meyer-Krahmer and Schmoch, 1998; Mowery and Sampat, 2005; D'Este and Patel, 2007; Perkmann and Walsh, 2009). In this regard Dutrénit and Arza (2010) provide evidence of important differences in the preferred channels of interaction used by both agents in four Latin American countries.

Channels of interaction can be grouped into different categories according to the degree of formality (Vedovello, 1997 and 1998; Fritsch and Schwirten, 1999; Schartinger, et al., 2002; D'Este and Patel, 2007; Wright, et al., 2008; Perkmann and Walsh, 2009; Eun, 2009; Cassiman, et al., 2010; Leisyte, 2011), the degree of interaction (Fritsch and Schwirten, 1999, Perkmann and Walsh, 2007; Santoro and Saparito, 2003; Schartinger, et al., 2002; Wright, et al., 2008), the direction of knowledge flows (Schartinger, et al., 2002; Arza, 2010) and the potential of obtaining applied results (Wright, et al., 2008; Perkmann and Walsh, 2009). Perkmann and Walsh (2009) found that some types of formal interaction, such as joint $\mathrm{R} \& \mathrm{D}$, result in academic publications, while this is less often the case for interactions such as contract research and consulting which have more applied objectives. Cassiman, et al. (2010) found that the type of channels of interaction used by multinational corporations varies with the type of knowledge involved in the interaction and the project-level characteristics. Arza (2010) argues that bi-directional learning channel (e.g., joint and contract research) and commercial channel (e.g., consultancy) may be the most effective way to convey novelty and therefore to allow technological upgrading. In this regard, Perkmann and Walsh (2009) assert that the forms of interaction grouped in these channels involve a higher level of articulation than other channels, thereby helping with the transmission of tacit knowledge.

From the PRO perspective, empirical evidence shows differences according to the nature and fields of research; individuals focused on applied research tend to favor the use of patents, human resources mobility, and collaborative research, while those involved in basic research favor publications and conferences (Meyer-Krahmer and Schmoch, 1998; D'Este and Patel, 2007; Bekkers and Freitas, 2008). Channels of interaction are also related to the degree of motivation to interact (D'Este and Perkmann, 2010) and to the innovation cycle (Wright, et al., 2008). From the viewpoint of industry, Schartinger, et al. (2002) and Cassiman, et al. (2010) emphasize the importance of using different channels, as it represents varying strategies to ensure research efficiency, allows access to different types of scientific and technological knowledge, and reflects differences in demand for knowledge according to the stages of innovation.

The emphasis on each channel or group of channels may be determined by the motivation to interact (Arza, 2010; D'Este and Perkmann, 2010) and the origin of financing (Bolli and Somogyi, 2011); these usually vary according to the field of knowledge and technology, and by the sector (Cohen, et al., 2002; Schartinger, et al., 2002; Laursen and Salter, 2004; Mowery and Sampat, 2005; Hanel and St-Pierre, 2006; Fontana, et al., 2006; Intarakumnerd and Schiller, 2009). As different sectors have different knowledge 
bases and innovation patterns (Pavitt, 1984; Asheim and Coenen, 2005), they also employ different ways of interacting with academia and other sources of knowledge. ${ }^{6}$

\subsection{Stage 3: Which are the main perceived benefits of interaction?}

Studies have shown that the perceived benefits from interaction are different for firms than for PRO. Firms benefit by obtaining a different perspective for the solution of problems and in some cases perform product or process innovation that, without interaction, could not have been possible (Rosenberg and Nelson, 1994). Researchers obtain ideas for publication and future research, test applications of a theory and knowledge exchange, make contacts with firms, derive a new perspective from which to approach industry problems and shape the knowledge produced by PRO, and secure funds for the laboratories and supplement funds for their own academic research (MeyerKrahmer and Schmoch, 1998; Lee, 2000; Welsh, et al., 2008).

Researchers and firms reap different sorts of benefits, which can be grouped in varying ways. From the PRO perspective, Arza (2010) grouped benefits into two main categories: economic and intellectual. Economic benefits refer to the obtaining of research inputs and the securing of funds for laboratories, the acquisition of supplement funds for the researchers' own academic research, and the obtaining financial resources. Intellectual benefits refer to knowledge exchange, ideas for new scientific and research projects, academic publications, scientific discoveries, new perspectives from which to approach industry problems, the development of human resources, and the possibility of shaping the knowledge that is being produced. Dutrénit and Arza (2010) analyze this classification of benefits for researchers of four Latin-American countries. Lee (2000) and Perkmann and Walsh (2009) also analyzed some of these benefits. Wright et al. (2008) argue that each specific channel of interaction tends to favor either economic or intellectual benefits.

From the perspective of firms, Arza (2010) groups the benefits into two categories: production and innovation. Production benefits refer to short-term issues such as new human resources (Bishop, et al., 2011), the use of resources available at PRO to perform tests and quality control, access to different approaches for problem-solving (Bishop, et al., 2011), and contributions to the completion of existing projects. Other authors have also emphasized the development of new products and processes close to this group (Rosenberg and Nelson, 1994; Lee, 2000; Cohen, et al., 2002). Innovation benefits refer to long-term issues, such as access to highly skilled research teams from PRO, the possibility of shaping the knowledge produced within academia, the identification of new R\&D projects (Cohen, et al., 2002), the selection or direction of firms' research projects (Eom and Lee 2010), technology licenses and patents (Lee, 2000; Bishop, et al., 2011),

\footnotetext{
${ }^{6}$ For biotechnology and pharmaceuticals, Cohen, et al. (2002) found that knowledge transfer by publications is more important. For chemistry, the important knowledge flows are patents, collaborative research and human resources mobility (Schartinger, et al., 2002), and scientific output, informal contacts, and students (Bekkers and Bodas Freitas, 2008). For electronics, the most important knowledge flows is human resources, especially through the hiring of students (Schartinger, et al., 2002; Balconi and Laboranti, 2006).
} 
and access to university research and discoveries (Lee, 2000; Cohen, et al., 2002; Zucker, et al., 2002). Dutrénit and Arza (2010) analyze this classification of benefits into production and innovation for firms of four Latin-American countries. Monjon and Waelbroeck (2003) found that whether benefits are derived from collaboration is firmspecific and depend on the firm's absorptive capacities to identify and exploit external knowledge.

Regarding the relationship between channels and benefits from interaction, most authors have analyzed the positive effect of joint and contract $R \& D$ on the benefits obtained either by researchers or by firms. Perkmann and Walsh (2009) found that joint R\&D often results in academic publications, while other types of collaboration with more practical objectives, such as contract research and consultancy, lead to publications only if researchers make efforts to exploit collaboration for research purposes. With regards to firms, Adams, et al. (2003), Hanel and St-Pierre (2006), and Arvanitis, et al. (2008) found that PRO-I interactions through R\&D bring different types of benefits, such as increases in innovation and productivity that have a positive impact on product development. Dutrénit, et al. (2010a) found that bi-directional (e.g., joint and contract research) and traditional (e.g., hiring of graduates) channels of interaction bring intellectual benefits to Mexican PRO, while bi-directional, traditional, and service (e.g., consultancy) channels bring production and innovation benefits for firms. Other Latin-American countries report some analogous results based on the same analytical framework. Arza and Vazquez (2010) found that bi-directional and the service channels bring intellectual benefits, and service channel yield economic benefits in the case of Argentinean researchers; traditional and bi-directional channels yield production and innovation benefits to Argentinean firms. Fernandes, et al. (2010) found that bi-directional, traditional, and service channels contribute to both intellectual and traditional benefits for university researchers, as well as to production benefits for firms, while bi-directional and traditional channels are relevant to innovation benefits.

In contrast, some works identified disadvantages of PRO-I interaction. They point out that a greater involvement with industry can corrupt academic research and teaching, by distracting attention from fundamental research. In addition, it can reduce the openness of communication among academic researchers and put restrictions on publishing, both of which are essential to academic research (Rosenberg and Nelson, 1994; Welsh, et al., 2008). The positive and negative aspects of interaction have brought some debate regarding the new role of academia regarding the increasing interaction with industry. Rosenberg and Nelson (1994) argue that, on the one hand, universities can and should play a larger and more direct role in assisting industry (a view held mostly by firms), while on the other hand, some researchers see these developments as a threat to the integrity of academic research (the view mostly of academics). Welsh, et al. (2008) stress that maximizing the benefits of academic research requires the development of policies that increase interaction while protecting the autonomy and freedom of researchers. This discussion is particularly relevant to developing countries, as universities could play an important role in their development, a process which requires greater focus on economic and social needs (Vessuri, 1998; Casas, de Gortari and Luna, 2000; Arocena and Sutz, 
2005; Albuquerque, et al., 2008; Maculan and Carvalho, 2009; Göransson and Brundenius, 2011).

\subsection{Conceiving of the linking process as a three-stage process}

This paper conceptualizes PRO-I linkages as a process that can be divided into three different stages: i) drivers of interaction; ii) channels of interaction (i.e., knowledge flows through different channels of interaction); and iii) the perceived benefits of collaboration.

As mentioned above, the literature generally approaches these stages independently and focuses either on one specific channel or links certain channels (mostly joint R\&D) and benefits. However, we suggest that there is a connection between the three stages namely that: different drivers to collaborate determine specific types of knowledge flows through certain channels, and these channels also have an impact on the specific benefits that agents perceive from interaction. Hence, obtaining a deeper understanding of the behavior of PRO's researchers and firms requires a systematic approach toward the linking process as a whole, with particular focus on its three stages. In addition, by analyzing how both agents use the same channels, it is possible to build connections among their behaviors. Based on micro data from the Mexican case, this paper empirically tests these links from the perspective of both agents. In particular, this paper explores the three stages and connects firms' benefits with researchers' characteristics through analysis of four different channels of interaction. Even though the literature on PRO-I interactions is quite broad, to our knowledge these specific aspects have not been approached in previous research.

\section{Methodology}

\subsection{Data collection and sample characteristics}

Our study is based on original data collected through two surveys conducted on PRO-I interactions and carried out in Mexico during 2008. R\&D and product development managers answered the Roks survey of firms, which includes questions about innovation and R\&D activities, sources of knowledge and forms of PRO-I interaction, the objectives of and benefits derived from interaction, and the perception of the main role of PRO. Researchers working at PRO answered the Roks survey of researchers, which includes researchers and team characteristics, forms of PRO-I interaction, and personal and institutional benefits from interaction.

Regarding researchers, the sample was constructed from the National Researchers System (NRS) database. Only researchers from six fields of knowledge were included (Physics \& Mathematics; Biology \& Chemistry; Medicine \& Health Sciences; Social Sciences; Biotechnology \& Agronomy; and Engineering). Initially the questionnaire was sent by e-mail to 10,100 researchers but the response rate was very low. We then turned to a shortlist, provided by CONACYT, of 2,043 researchers from all the fields of knowledge that are quite active in applying for public grants. We complemented this list with one of 1,380 researchers working in engineering departments of the main PRO in order to include researchers that do not belong to the NRS but tend to have linkages with 
firms. Eventually the response rate was $14 \%$. For this paper, the sample consisted of 385 researchers ascribed to PRO, with $81 \%$ of them belonging to the NRS and $61 \%$ having links with industry.

The distribution of researchers' fields in the sampe is as follows: $17 \%$ in Physics \& Mathematics, 23\% in Biology \& Chemistry, 6\% in Medicine \& Health Sciences, 24\% Biotechnology \& Agronomy, and 30\% in Engineering. Of the researchers, $87 \%$ have a $\mathrm{PhD}, 7 \%$ a master's degree, and $6 \%$ only an undergraduate degree. In terms of the institutional affiliation, $58 \%$ of researchers work at universities. Within PRO, researchers from centers tend to connect more than those affiliated with universities $(75 \%$ and $51 \%$, respectively). In the total sample, $71 \%$ of researchers belong to a research group, and $61 \%$ of the research groups have links with firms. Regarding the research type, $52.7 \%$ of researchers do basic science, $26.8 \%$ applied science, and $20.5 \%$ technology development. On average, research groups consist of 6 members (including $\mathrm{PhDs}$, post-docs, and technicians).

Regarding firms, the sample was constructed from lists of firms that have participated in various programs managed by federal and regional government agencies, such as fiscal incentives for R\&D and sectoral funds. ${ }^{7}$ The firms' database was composed of 1,200 firms; $70 \%$ of them have benefited from public funds to foster R\&D and innovation activities. The response rate was 32.3\%. For this paper, the sample consisted of 325 innovative firms from all manufacturing sectors; non-innovative firms were excluded. ${ }^{8}$ Of those 325, 67\% are R\&D performers, $42 \%$ have obtained fiscal incentives for R\&D, and $75 \%$ have links with PRO (with $67 \%$ interacting with universities and $47 \%$ with centers). The linked and unlinked firms differ by sectors. The characteristics of this sample do not differ from results obtained by the National Innovation Survey of 2006, where half of the innovators perform R\&D activities and $65 \%$ use PRO as an information source.

Linked firms have larger R\&D departments, $85 \%$ of them employ a human resource base that is highly skilled to perform $\mathrm{R} \& \mathrm{D}$ activities and tend to use other information sources more extensively than those without links. Firms that benefited from fiscal incentives for R\&D have a higher tendency to interact than otherwise, as $84 \%$ of them have links with industry. Firms with foreign investment represent $33 \%$ of the total sample; they have about the same tendency to interact as nationally owned firms (70\%). In terms of the size of firms, most are medium-sized (42\%) and large (42\%); only 16\% are micro and small. Micro/small and large firms tend to interact more $(80 \%)$ than medium-sized firms $(68 \%)$.

Participation in both surveys was voluntary; thus there is probably a response bias towards PRO-I interaction regarding those researchers and firms that actually interact and

\footnotetext{
${ }^{7}$ The program of sectoral funds is composed of 20 funds operated in conjunction with some ministries or other governmental organizations to promote the development and consolidation of STI capabilities according to the strategic needs of each participating sector. It includes an innovation fund with the Ministry of Economy.

${ }^{8} \mathrm{We}$ consider innovative firms to be those that have performed product or process innovation at the firm, country or world level within a three-year period prior to the survey.
} 
were keener to answer this questionnaire. In addition, the firms' survey includes a large proportion of firms that have obtained public funds to foster R\&D; thus they may perform R\&D activities more, and interact more with PRO, than others.

\subsection{Construction of variables}

We conducted a systematic analysis of the three stages of the linking process for firms and researchers. The first stage focuses on the analysis of drivers of interaction; we identify the impact of different variables that affect the probability of linking by researchers and firms. The second stage focuses on the analysis of channels of interaction; we identify the impact of different variables that affect the preferences for different channels. The analysis of the second stage was performed only for researchers and firms that actually interact, correcting for a possible selection bias. In the third stage we identify the impact of different variables on the perceived benefits by both researchers and firms; we incorporate the predictors from stage two to identify the particular impact of each channel of interaction on the benefits of interaction.

The key variable for stage two is channels of interaction, and for stage three, benefits from interaction. To build the variable 'channels of interaction', we relied on a question that asked researchers and firms to evaluate the importance of each form of interaction. Ten forms of interaction were classified into four channels following a methodology of factor analysis by factor reduction (Table 1). ${ }^{9}$ The results of the classification of firms and researchers are similar; however, the factor loads for each form of interaction for firms and researchers within the same channel differ.

Table 1 Channels of PRO-industry interaction

\begin{tabular}{|c|c|}
\hline Channels of interaction & Forms of interaction \\
\hline $\begin{array}{l}\text { Information \& training } \\
\text { (InfoChannel) }\end{array}$ & $\begin{array}{c}\text { Publications } \\
\text { Conferences } \\
\text { Informal information } \\
\text { Training } \\
\end{array}$ \\
\hline $\begin{array}{l}\text { R\&D projects \& consultancy } \\
\text { (ProjectChannel) }\end{array}$ & $\begin{array}{c}\text { Contract R\&D } \\
\text { Joint R\&D } \\
\text { Consultancy }\end{array}$ \\
\hline $\begin{array}{l}\text { Intellectual property rights } \\
\text { (IPRChannel) }\end{array}$ & $\begin{array}{c}\text { Technology licenses } \\
\text { Patents }\end{array}$ \\
\hline $\begin{array}{l}\text { Human resources } \\
\text { (HRChannel) }\end{array}$ & Hiring of recent graduates \\
\hline
\end{tabular}

To build the variable 'benefits' for researchers and firms, we analyzed a question where the two groups evaluated the importance of each benefit of interaction. For firms'

\footnotetext{
${ }^{9}$ Tables A.1 and A.2 in the Appendix present the rotated matrix for channels of interaction for firms and researchers, respectively.
} 
benefits, we relied on a question where firms evaluated the importance of achieving specific objectives from their interaction with PRO; we considered only the cases where firms evaluated the results of interaction as positive. Drawing on ten individual benefits, we identified three types of benefits from interaction following a methodology of factor analysis by factor reduction (Table 2). ${ }^{10}$

Table 2 Type of benefits for firms

\begin{tabular}{|c|c|}
\hline Group of Benefits & Individual Benefits \\
\hline $\begin{array}{l}\text { Strengthening capabilities based } \\
\text { on R\&D (RDCapB) }\end{array}$ & $\begin{array}{l}\text { Acquisition of complementary R\&D } \\
\text { Acquisition of substitute R\&D } \\
\text { Use of resources available at PRO }\end{array}$ \\
\hline $\begin{array}{l}\text { Strengthening capabilities based } \\
\text { on innovation activities other than } \\
\text { R\&D (non-RDCapB) }\end{array}$ & $\begin{array}{l}\text { Technology transfer from PRO } \\
\text { Acquisition of knowledge to solve production } \\
\text { problems } \\
\text { Increase of firms' ability to find and absorb } \\
\text { technological information } \\
\text { Acquisition of information about trends in R\&D } \\
\text { Access to qualified human resources }\end{array}$ \\
\hline Improving quality (QualB) & $\begin{array}{l}\text { Test of products/processes } \\
\text { Increase in quality control }\end{array}$ \\
\hline
\end{tabular}

To build the variable of researchers' benefits, we relied on a question asking researchers to evaluate the importance of benefits during their interaction with firms. We performed a factor analysis by factor reduction and grouped the benefits into two factors: economic benefits (EconomicB) and intellectual benefits (IntellectualB) (Table 3). ${ }^{11}$

Table 3 Type of benefits for researchers

\begin{tabular}{cl}
\hline \multicolumn{1}{c}{ Group of Benefits } & \multicolumn{1}{c}{ Individual Benefits } \\
\hline & Ideas for further collaborative projects \\
Intellectual (IntellectualB) & Ideas for further research \\
& Knowledge/information sharing \\
& Reputation \\
\hline \multirow{2}{*}{ Economic (EconomicB) } & Sharing of equipment/instruments \\
& Provision of research inputs \\
& Financial resources \\
\hline
\end{tabular}

We also identified different independent variables that affect each of the three stages of the linking process for researchers and firms. Drawing on the literature, for firms we analyzed variables related to structural factors, such as firms' characteristics (size, sector, and ownership), and variables related to behavioral factors (R\&D capabilities, innovation strategy, and linking strategy with PRO). Regarding innovation strategy, one of the

\footnotetext{
${ }^{10}$ Table A.3 in the Appendix presents the rotated matrix for firms' benefits.

${ }^{11}$ Table A.4 in the Appendix presents the rotated matrix for researchers' benefits. We draw on the concepts proposed by Arza (2010).
} 
variables we analyzed was openness strategy. Drawing on Laursen and Salter (2004) ${ }^{12}$ to build four factors by principal components that express the firm's openness strategy to obtaining information from external sources ${ }^{13}$ (Table 4). For researchers we analyzed individual factors (knowledge skills, experience, and academic collaboration) and institutional factors (institutional affiliation, and linking strategy with firms) (Table 5).

\footnotetext{
${ }^{12}$ Laursen and Salter (2004) argue that management factors, such as the extent to which firms rely on different types of information sources, are important drivers of collaboration and derive benefits from academia. They built a variable that reflects firms' search strategies. From a pool of 15 information sources, excluding 'universities' and 'within the firm', they performed a factor analysis using principal components and obtained two factors for openness strategy.

${ }^{13}$ The common explained variance by these factors is $66.1 \%$. See Table A.5 in the Appendix for a better description of the factor analysis.
} 
Table 4 Variables for analyzing PRO-industry linkages from the firms' perspective

\begin{tabular}{|c|c|c|c|c|c|c|c|}
\hline Broad Concept & Variables & Definition of variables & Mean & St. Dev. & Min & Max & Stage \\
\hline Collaboration & Collaboration (COLLPRO) & $\begin{array}{l}\text { Dummy: collaborate }=1 \text {, do not } \\
\text { collaborate }=0\end{array}$ & 0.754 & 0.431 & 0 & 1 & 1 \\
\hline \multirow{5}{*}{ Channels of interaction } & & \multirow{5}{*}{$\begin{array}{l}\text { Numerical: Factor loads from factor } \\
\text { reduction }\end{array}$} & $8.07 \mathrm{E}-07$ & 1 & -2.754 & 2.593 & \multirow{5}{*}{2} \\
\hline & Information \& training (InfoChannel) & & $-8.67 \mathrm{E}-07$ & 1 & -2.358 & 3.033 & \\
\hline & R\&D projects \& consultancy (ProjectChannel) & & & & & & \\
\hline & $\begin{array}{l}\text { Intellectual property rights (IPRChannel) } \\
\text { Human resources (HRChannel) }\end{array}$ & & $4.76 \mathrm{E}-07$ & 1 & -2.654 & 3.222 & \\
\hline & & & $-1.52 \mathrm{E}-06$ & 1 & -2.487 & 2.669 & \\
\hline \multirow{3}{*}{ Benefits from interaction } & Strengthening capabilities based on R\&D & \multirow{3}{*}{$\begin{array}{l}\text { Numerical: Factor loads from factor } \\
\text { reduction }\end{array}$} & $1.14 \mathrm{E}-08$ & 1.340 & -3.648 & 4.973 & \multirow{3}{*}{3} \\
\hline & $\begin{array}{l}\text { (RDCapB) } \\
\text { Strengthening capabilities based on innovation } \\
\text { activities other than R\&D (non-RDCapB) }\end{array}$ & & $-2.80 \mathrm{E}-09$ & 1.443 & -3.692 & 4.969 & \\
\hline & Improving quality (QualB) & & $-1.23 \mathrm{E}-08$ & 1.631 & -3.807 & 5.152 & \\
\hline \multirow{3}{*}{ Firms' characteristics } & Firm size (LNEMPL) & Numerical: $\ln$ of firms' employees & 5.330 & 1.566 & 1.1 & 10 & 1 \\
\hline & Technology sector level (TECHLEVEL) & \multirow{2}{*}{$\begin{array}{l}\text { Categorical: low }=0.25 ; \text { medium-low }=0.5 ; \\
\text { medium-high }=0.75 ; \text { high }=1 \\
\text { Dummy: Foreign investment }=1 \text {, National } \\
\text { investment }=0\end{array}$} & 0.577 & 0.255 & 0.25 & 1 & 1 \\
\hline & Ownership (ownership) & & 0.329 & 0.471 & 0 & 1 & 1,2 \\
\hline \multirow{2}{*}{$\begin{array}{l}\text { Effort to increase } R \& D \\
\text { capabilities }\end{array}$} & Human resources in R\&D (RATIOHR) & $\begin{array}{l}\text { Numerical: Human resources in R\&D as \% } \\
\text { of the total employment }\end{array}$ & 6.551 & 11.681 & 0.028 & 100 & $1,2,3$ \\
\hline & Formalization of R\&D activities (FORMAL) & $\begin{array}{l}\text { Dummy: Formal and continuous R\&D } \\
\text { activities }=1 \text {, otherwise }=0\end{array}$ & 0.745 & 0.436 & 0 & 1 & 1,2 \\
\hline \multirow{5}{*}{ Innovation strategy } & Fiscal incentives R\&D (FI) & Dummy: yes $=1$, no $=0$ & 0.418 & 0.494 & 0 & 1 & 1,2 \\
\hline & $\begin{array}{l}\text { Openness strategy: } \\
\text { Access to open information (OpEstF1) }\end{array}$ & \multirow{4}{*}{$\begin{array}{l}\text { Factor loads from factor analysis of } \\
\text { external sources of information for F1-F4 }\end{array}$} & 0 & 1.000 & -2.066 & 1.936 & \multirow{4}{*}{1} \\
\hline & $\begin{array}{l}\text { Consulting and research projects with other firms } \\
\text { (OpEstF2) }\end{array}$ & & 0 & 1.000 & -1.266 & 2.831 & \\
\hline & Market (OpEstF3) & & 0 & 1.000 & -2.404 & 1.865 & \\
\hline & Suppliers (OpEstF4) & & $3.75 \mathrm{E}-06$ & 1.000 & -1.687 & 1.824 & \\
\hline \multirow{5}{*}{ Linking strategy with PRO } & Type of PRO & Three dummy variables: & & & & & \multirow{4}{*}{2} \\
\hline & Links with both (linkboth) & Links with both $=1$ & 0.387 & 0.487 & 0 & 1 & \\
\hline & Links with universities only (linkonlyUn) & Links with universities $=1$ & 0.283 & 0.451 & 0 & 1 & \\
\hline & Links with centers only (linkonlyCen) & Links with centers $=1$ & 0.083 & 0.276 & 0 & 1 & \\
\hline & Duration of links (TIME) & $\begin{array}{l}\text { Dummy: one year or more }=1 \text {, } \\
\text { less than } 1 \text { year }=0\end{array}$ & 0.808 & 0.395 & 0 & 1 & 3 \\
\hline
\end{tabular}


Table 5 Variables for analyzing PRO-I linkages from the researchers' perspective

\begin{tabular}{|c|c|c|c|c|c|c|c|}
\hline Broad Concept & Variables & Definition of variables & Mean & St. Dev. & Min & Max & Stage \\
\hline Collaboration & Collaboration (collaborate) & $\begin{array}{l}\text { Dummy: collaborate }=1 \text {, do not } \\
\text { collaborate }=0\end{array}$ & 0.610 & 0.488 & 0 & 1 & 1 \\
\hline \multirow{5}{*}{ Channels of interaction } & & \multirow{5}{*}{$\begin{array}{l}\text { Numerical: Factor loads from factor } \\
\text { reduction }\end{array}$} & $-1.08 \mathrm{E}-16$ & 1 & -2.957 & 2.381 & \multirow{5}{*}{2} \\
\hline & Information \& training (InfoChannel) & & & & & & \\
\hline & $\begin{array}{l}\text { Intellectual property rights (IPRChannel) } \\
\text { R\&D projects \& consultancy (ProjectChannel) }\end{array}$ & & $9.87 \mathrm{E}-17$ & 1 & -2.454 & 2.486 & \\
\hline & Human resources (HRChannel) & & $3.06 \mathrm{E}-17$ & 1 & -2.361 & 2.710 & \\
\hline & & & $-9.64 \mathrm{E}-17$ & 1 & -2.258 & 2.884 & \\
\hline \multirow{2}{*}{ Benefits from interaction } & Intellectual (IntellectualB) & Numerical: Factor loads from factor & $1.76 \mathrm{E}-16$ & 1 & -2.761 & 2.049 & \multirow{2}{*}{3} \\
\hline & Economic (EconomicB) & reduction & $3.77 \mathrm{E}-17$ & 1 & -1.987 & 2.870 & \\
\hline \multirow{13}{*}{ Knowledge skills } & $\mathrm{PhD}(\mathrm{PhD})$ & Dummy: $\mathrm{PhD}=1$ & 0.870 & 0.337 & 0 & 1 & 1,2 \\
\hline & Years of experience (Timedegree) & $\begin{array}{l}\text { Numerical: Number of years between the } \\
\text { highest degree and the year of the survey }\end{array}$ & 10.8 & 9 & 0 & 51 & 3 \\
\hline & Experience with large firms (Explarge) & Dummy: experience $=1$, no $=0$ & 0.111 & 0.314 & 0 & 1 & 3 \\
\hline & Type of research & Dummy: & & & & & \multirow{4}{*}{$1,2,3$} \\
\hline & Basic (basic) & Basic science $=1$ & 0.527 & 0.500 & 0 & 1 & \\
\hline & Technology development (technology) & Technology development $=1$ & 0.205 & 0.404 & 0 & 1 & \\
\hline & Applied (applied) & Applied science $=0$ & 0.268 & 0.443 & 0 & 1 & \\
\hline & Area of knowledge & Five dummy variables: & & & & & \multirow{6}{*}{1,2} \\
\hline & Physics \& Mathematics (area1) & Physics \& Mathematics=1 & 0.169 & 0.375 & 0 & 1 & \\
\hline & Biology \& Chemistry (area2) & Biology \& Chemistry=1 & 0.226 & 0.419 & 0 & 1 & \\
\hline & Medicine \& Health Sciences (area3) & Medicine \& Health Sciences $=0$ & 0.062 & 0.242 & 0 & 1 & \\
\hline & Biotechnology \& Agronomy (area4) & Biotechnology \& Agronomy=1 & 0.239 & 0.427 & 0 & 1 & \\
\hline & Engineering (area5) & Engineering $=1$ & 0.304 & 0.461 & 0 & 1 & \\
\hline Institutional affiliation & Type of organization (Type) & $\begin{array}{l}\text { Dummy: university }=1, \\
\text { center }=0\end{array}$ & 0.584 & 0.493 & 0 & 1 & 1,2 \\
\hline \multirow{3}{*}{ Academic collaboration } & Research team with peer PhD (Peer) & Dummy: peer $\mathrm{PhD}=1, \mathrm{no}=0$ & 0.623 & 0.485 & 0 & 1 & 3 \\
\hline & Team age (Teamage) & $\begin{array}{l}\text { Numerical: Number of years between the } \\
\text { creation of the group and the year of the } \\
\text { survey }\end{array}$ & 8.008 & 10.612 & 0 & 56 & 2 \\
\hline & $\begin{array}{l}\text { No. of researchers, } \mathrm{PhD} \text { and technicians } \\
\text { (Teamsize) }\end{array}$ & $\begin{array}{l}\text { Numerical: Number of researchers that } \\
\text { participate in the team }\end{array}$ & 6.392 & 16.738 & 0 & 56 & 2 \\
\hline \multirow{5}{*}{ Linking strategy with firms } & $\begin{array}{l}\text { Initiative to collaborate by researcher } \\
\text { (researcher) }\end{array}$ & $\begin{array}{l}\text { Two dummy variables: } \\
\text { Researcher' initiative }=1, \text { no }=0\end{array}$ & 0.317 & 0.466 & 0 & 1 & \multirow[t]{2}{*}{3} \\
\hline & Initiative to collaborate by firm (firm) & Firms' initiative $=1$, no $=0$ & 0.081 & 0.272 & 0 & 1 & \\
\hline & & Two dummy variables: & & & & & \\
\hline & Financing projects & Public financing $=1, \mathrm{no}=0$ & 0.883 & 0.322 & 0 & 1 & 2 \\
\hline & $\begin{array}{l}\text { Research financed by public agencies (PublicF) } \\
\text { Research financed by firms (FirmF) }\end{array}$ & Firm financin $\mathrm{g}=1$ no $=0$ & 0193 & 0395 & 0 & 1 & 3 \\
\hline
\end{tabular}




\subsection{The model}

Following a three-stage model based on Crépon, et al. (1998), we conceptualized PRO-I linkages as a systematic process that can be explored through three different stages: i) drivers of interaction, ii) channels of interaction, and iii) the perceived benefits of collaboration. We suggest that different drivers of collaboration favor specific types of channels of interaction, and that these specific types of channels favor certain benefits of interaction.

Our model consists of three equations, one for each stage of the linking process. We used a Heckman two-step estimation model for the first and second stages (Heckman, 1978), which helps isolate the factors that affect the selection process and reduces the selection bias. In the first stage of the model (drivers), a Probit regression is computed to identify the main drivers that affect the probability of linking. The dependent variable $\left(d_{i}\right)$ is a dummy variable that equals 1 when the firm or researcher is connected. The vectors of independent variables in these equations are those features of researchers $\left(R D_{i}\right)$ and firms $\left(F D_{i}\right)$ that affect their probability of linking. This stage also estimates the inverse mills ratio for each researcher or firm, which is used as an instrument in the second regression to correct the selection bias. The second equation (channels) is a linear regression to identify the main determinants of the channels of interaction. The dependent variable $\left(c_{i}\right)$ is a pseudo-continuous variable that expresses the importance of the channels of interaction. The vectors of independent variables are those features of researchers $\left(R C_{i}\right)$ and firms $\left(F C_{i}\right)$ that determine the specific channels. We conceptualized one equation for each type of channel for researchers and firms. We performed the second equation only for those firms and researchers that actually interact, using the inverse mills ratio from the first equation to correct for a possible selection bias. During the third stage (benefits), we build a linear regression to identify the main determinants of obtaining benefits from collaboration. The dependent variable $\left(b_{i}\right)$ is a pseudo-continuous variable that expresses the importance of benefits from interaction. The vectors of independent variables are those features of researchers $\left(R B_{i}\right)$ and firms $\left(F B_{i}\right)$ that determine the specific benefits of interaction. We developed one equation for each type of benefit for researchers and for firms. During this stage we incorporate the predicted values from each channel of interaction from equation (2). As we identified three types of benefits for firms and two types of benefits for researchers, we have a set of three equations for firms and a set of two equations for researchers. Following this methodology it is possible to identify the impact of drivers on channels of interaction, and the impact of channels on the benefits of interaction for each agent. This methodology also allows connecting firms' benefits and researchers' features/characteristics for each channel of interaction in an indirect way.

a) Model 1. Firms:

$$
\begin{aligned}
& \text { (1.1) } \quad d_{i}=F D_{i} \beta+\varepsilon_{i} \\
& \text { (1.2.1) } c_{i} \text { Info }=F C_{i} \beta+\varepsilon_{i} \\
& \text { (1.2.2) } c_{i} \text { Project }=F C_{i} \beta+\varepsilon_{i} \\
& \text { (1.2.3) } c_{i} \text { IPR }=F C_{i} \beta+\varepsilon_{i} \\
& \text { (1.2.4) } c_{i} H R=F C_{i} \beta+\varepsilon_{i}
\end{aligned}
$$




$$
\begin{aligned}
& \text { (1.3.1) } b_{i} R D C a p B=\alpha_{i} c_{i}+F B_{i} \beta+\varepsilon_{i} \\
& \text { (1.3.2) } b_{i} \text { non-RDCapB }=\alpha_{i} c_{i}+F B_{i} \beta+\varepsilon_{i} \\
& \text { (1.3.3) } b_{i} \text { QualB }=\alpha_{i} c_{i}+F B_{i} \beta+\varepsilon_{i}
\end{aligned}
$$

Where:

$d_{i}$ is a dummy variable that expresses collaboration with PRO for firm $i$.

$c_{i}$ expresses four different types of channels of interaction (Information $\&$ training, $\mathrm{R} \& \mathrm{D}$ Projects \& Consultancy, Intellectual property rights, and Human resources).

$b_{i}$ express three different types of benefits for firm $i$ (Strengthening capabilities based on $\mathrm{R} \& \mathrm{D}$, Strengthening capabilities based on other innovation activities, and Improving quality).

$F D_{i}$ is a vector of explanatory variables for drivers of interaction: human resources in $R \& D$, formalization of $R \& D$ and innovation activities, firm size, technology sector level, ownership, fiscal incentives for $R \& D$, and openness strategy.

$F C_{i}$ is a vector of explanatory variables for channels of interaction: human resources in $R \& D$, formalization of $R \& D$ and innovation activities, links with both, links with universities only, links with centers only, ownership, fiscal incentives for $R \& D$.

$F B_{i}$ is a vector of explanatory variables for benefits from collaboration: human resources in $R \& D$, duration of links.

$\alpha_{i} c_{i}$ are the predicted values for equation (1.2); they are associated with each type of channel of interaction (Information \& training, R\&D projects \& consultancy, Intellectual property rights, and Human resources).

Table 6 lists the variables used in each equation.

b) Model 2. Researchers:

$$
\begin{aligned}
& \text { (2.1) } d_{i}=R D_{i} \beta+\varepsilon_{i} \\
& \text { (2.2.1) } c_{i} \text { Info }=R C_{i} \beta+\varepsilon_{i} \\
& \text { (2.2.2) } c_{i} \text { IPR }=R C_{i} \beta+\varepsilon_{i} \\
& \text { (2.2.3) } c_{i} \text { Project }=R C_{i} \beta+\varepsilon_{i} \\
& \text { (2.2.4) } c_{i} H R=R C_{i} \beta+\varepsilon_{i} \\
& \text { (2.3.1) } b_{i} \text { IntellctualB }=\alpha_{i} c_{i}+R B_{i} \beta+\varepsilon_{i} \\
& \text { (2.3.2) } b_{i} \text { Economic } B=\alpha_{i} c_{i}+R B_{i} \beta+\varepsilon_{i}
\end{aligned}
$$

Where:

$d_{i}$ is a dummy variable that expresses collaboration with firms for PRO $i$.

$c_{i}$ expresses four different types of knowledge flows (Information $\&$ training, R\&D projects \& consultancy, Intellectual property rights, and Human resources).

$b_{i}$ expresses two different types of benefits for PRO $i$ (intellectual and economic).

$R D_{i}$ is a vector of explanatory variables for drivers of interaction: degree, type of research, area of knowledge, and type of organization.

$R C_{i}$ is a vector of explanatory variables for channels of interaction: degree, area of knowledge, team size, team age, and public financing. 
$F B_{\mathrm{i}}$ is a vector of explanatory variables for benefits from collaboration: experience, type of research, type of organization, academic collaboration, private financing, and initiative of collaboration.

$a_{i} c_{i}$ are the predicted values for equation (2.2); they are associated with each channel of interaction (Information \& training, R\&D projects \& consultancy, Intellectual property rights, and Human resources).

Table 7 lists the variables used in each equation.

\section{$4 \quad$ Main findings}

The results of our analysis suggest that academia is an important source of knowledge for firms, and that PRO-I interaction represents an important source of ideas that shape knowledge produced within academia. This paper focuses on the firms' point of view - in particular, on the best channels of interaction for them - and identifies the main researchers characteristics that contribute to strengthening long-term benefits for firms that emerge from interaction; this discussion is provided in section 4.3. This paper also discusses certain differences within the three stages of the linking process. On the one hand, firms and PRO have different drivers of collaboration and tend to prefer diverse channels of interaction; on the other hand, the impact of these channels on specific benefits differs. This analysis is provided in sections 4.1 and 4.2.

\subsection{Firms}

Table 6 presents the results of the regression model for equations (1.1), (1.2.1), (1.2.2), (1.2.3), (1.2.4), (1.3.1), (1.3.2), and (1.3.3) for firms. We observe that the coefficients of the four different selection equations (1.1) do not vary greatly, and that Prob>chi ${ }^{2}$ is significant in the four equations for channels of interaction. Thus, the results of these equations reflect a robust Heckman model. 
Table 6 Regression models for firms

\begin{tabular}{|c|c|c|c|c|c|c|c|c|c|c|c|}
\hline & $\begin{array}{c}\text { Selection } \\
(1.1)\end{array}$ & $\begin{array}{c}\text { InfoChannel } \\
(1.2 .1)\end{array}$ & $\begin{array}{c}\text { Selection } \\
(1.1)\end{array}$ & $\begin{array}{c}\text { ProjectChannel } \\
(1.2 .2)\end{array}$ & $\begin{array}{c}\text { Selection } \\
(1.1)\end{array}$ & $\begin{array}{c}\text { IPRChannel } \\
(1.2 .3) \\
\end{array}$ & $\begin{array}{c}\text { Selection } \\
(1.1)\end{array}$ & $\begin{array}{c}\text { HRChannel } \\
(1.2 .4)\end{array}$ & $\begin{array}{c}\text { RDCapB } \\
(1.3 .1) \\
\end{array}$ & $\begin{array}{c}\text { non-RDCapB } \\
(1.3 .2) \\
\end{array}$ & $\begin{array}{l}\text { QualB } \\
(1.3 .3) \\
\end{array}$ \\
\hline aInfoChannel $(a \mathrm{C} 1)$ & & & & & & & & & $\begin{array}{l}-0.616 \\
(0.613) \\
\end{array}$ & $\begin{array}{c}0.416 \\
(0.682) \\
\end{array}$ & $\begin{array}{c}(1.712)^{* * *} \\
(0.800) \\
\end{array}$ \\
\hline$a$ ProjectChannel ( $a \mathrm{C} 3$ ) & & & & & & & & & $\begin{array}{c}1.178 * * * \\
(0.410)\end{array}$ & $\begin{array}{l}-0.522 \\
(0.455)\end{array}$ & $\begin{array}{c}(-0.601) \\
(0.534)\end{array}$ \\
\hline$a$ IPRChannel $(a \mathrm{C} 2)$ & & & & & & & & & $\begin{array}{c}0.800^{* *} \\
(0.400)\end{array}$ & $\begin{array}{c}0.381 \\
(0.444) \\
\end{array}$ & $\begin{array}{c}(-0.445) \\
(0.521) \\
\end{array}$ \\
\hline$a$ HRChannel ( $a \mathrm{C} 4)$ & & & & & & & & & $\begin{array}{l}0.454^{* * *} \\
(0.236) \\
\end{array}$ & $\begin{array}{l}0.559 * * \\
(0.262) \\
\end{array}$ & $\begin{array}{c}(-0.321) \\
(0.307) \\
\end{array}$ \\
\hline Firm size (LNEMPL) & $\begin{array}{c}0.049 \\
(0.071)\end{array}$ & & $\begin{array}{c}0.057 \\
(0.071) \\
\end{array}$ & & $\begin{array}{l}-0.010 \\
(0.072) \\
\end{array}$ & & $\begin{array}{c}0.039 \\
(0.076)\end{array}$ & & & & \\
\hline $\begin{array}{l}\text { Technology sector level } \\
\text { (TECHLEVEL) }\end{array}$ & $\begin{array}{c}0.033 \\
(0.350) \\
\end{array}$ & & $\begin{array}{l}-0.189 \\
(0.622) \\
\end{array}$ & & $\begin{array}{c}0.079 \\
(0.325) \\
\end{array}$ & & $\begin{array}{c}0.080 \\
(0.354) \\
\end{array}$ & & & & \\
\hline Ownership (ownership) & $\begin{array}{c}0.047 \\
(0.191)\end{array}$ & $\begin{array}{l}-0.247^{*} \\
(0.142)\end{array}$ & $\begin{array}{c}0.060 \\
(0.204)\end{array}$ & $\begin{array}{c}0.064 \\
(0.142)\end{array}$ & $\begin{array}{c}0.156 \\
(0.198)\end{array}$ & $\begin{array}{l}-0.227^{*} \\
(0.146)\end{array}$ & $\begin{array}{c}0.019 \\
(0.195)\end{array}$ & $\begin{array}{c}0.098 \\
(0.133)\end{array}$ & & & \\
\hline $\begin{array}{l}\text { Human resources in } \\
\text { R\&D (RATIOHR) }\end{array}$ & $\begin{array}{c}0.014 \\
(0.013) \\
\end{array}$ & $\begin{array}{l}0.000 \\
(0.004)\end{array}$ & $\begin{array}{c}0.015 \\
(0.012) \\
\end{array}$ & $\begin{array}{c}0.006 \\
(0.006)\end{array}$ & $\begin{array}{c}0.007 \\
(0.012)\end{array}$ & $\begin{array}{c}0.004 \\
(0.006)\end{array}$ & $\begin{array}{c}0.016 \\
(0.014) \\
\end{array}$ & $\begin{array}{c}0.000 \\
(0.005)\end{array}$ & $\begin{array}{l}0.014 * \\
(0.008)\end{array}$ & $\begin{array}{l}0.000 \\
(0.009)\end{array}$ & $\begin{array}{c}(-0.002) \\
(0.010) \\
\end{array}$ \\
\hline $\begin{array}{l}\text { Formalization of R\&D } \\
\text { activities (FORMAL) }\end{array}$ & $\begin{array}{c}0.612 * * * \\
(0.195)\end{array}$ & $\begin{array}{l}-0.273^{*} \\
(0.166) \\
\end{array}$ & $\begin{array}{c}0.608^{* * * *} \\
(0.195)\end{array}$ & $\begin{array}{l}-0.086 \\
(0.239) \\
\end{array}$ & $\begin{array}{c}0.649 * * * \\
(0.193)\end{array}$ & $\begin{array}{l}-0.020 \\
(0.158) \\
\end{array}$ & $\begin{array}{c}0.643 * * * \\
(0.191)\end{array}$ & $\begin{array}{c}0.067 \\
(0.168) \\
\end{array}$ & & & \\
\hline $\begin{array}{l}\text { Fiscal incentives for } \\
\text { R\&D (FI) }\end{array}$ & $\begin{array}{l}0.248^{*} \\
(0.188) \\
\end{array}$ & $\begin{array}{c}0.104 \\
(0.144)\end{array}$ & $\begin{array}{l}0.303^{*} \\
(0.194) \\
\end{array}$ & $\begin{array}{l}0.280 * \\
(0.180)\end{array}$ & $\begin{array}{c}0.375^{* *} \\
(0.189) \\
\end{array}$ & $\begin{array}{c}0.489 * * * \\
(0.138)\end{array}$ & $\begin{array}{l}0.296^{*} \\
(0.189) \\
\end{array}$ & $\begin{array}{l}-0.383^{*} \\
(0.138)\end{array}$ & & & \\
\hline $\begin{array}{l}\text { Access to open } \\
\text { information (OpEstF1) }\end{array}$ & $\begin{array}{l}0.236^{* *} \\
(0.085) \\
\end{array}$ & & $\begin{array}{l}0.183^{*} \\
(0.118) \\
\end{array}$ & & $\begin{array}{c}0.253 * * * \\
(0.083)\end{array}$ & & $\begin{array}{l}0.194 * * \\
(0.092) \\
\end{array}$ & & & & \\
\hline $\begin{array}{l}\text { Consulting and research } \\
\text { projects with other firms } \\
\text { (OpEstF2) }\end{array}$ & $\begin{array}{c}0.350 * * * \\
(0.108)\end{array}$ & & $\begin{array}{c}0.305^{* *} \\
(0.114)\end{array}$ & & $\begin{array}{c}0.294 * * * \\
(0.089)\end{array}$ & & $\begin{array}{c}0.268 * * * \\
(0.096)\end{array}$ & & & & \\
\hline Market (OpEstF3) & $\begin{array}{c}0.095 \\
(0.079) \\
\end{array}$ & & $\begin{array}{c}0.057 \\
(0.088) \\
\end{array}$ & & $\begin{array}{c}0.082 \\
(0.077) \\
\end{array}$ & & $\begin{array}{c}0.082 \\
(0.080) \\
\end{array}$ & & & & \\
\hline Suppliers (OpEstF4) & $\begin{array}{l}0.237 * * \\
(0.089) \\
\end{array}$ & & $\begin{array}{l}0.190^{*} \\
(0.147)\end{array}$ & & $\begin{array}{c}0.224 * * \\
(0.087) \\
\end{array}$ & & $\begin{array}{l}0.276 * * \\
(0.089) \\
\end{array}$ & & & & \\
\hline $\begin{array}{l}\text { Links with both } \\
\text { (Linkboth) }\end{array}$ & & $\begin{array}{c}0.196 \\
(0.216) \\
\end{array}$ & & $\begin{array}{l}0.348^{* *} \\
(0.181)\end{array}$ & & $\begin{array}{c}0.146 \\
(0.162) \\
\end{array}$ & & $\begin{array}{c}1.068 * * * \\
(0.211)\end{array}$ & & & \\
\hline $\begin{array}{l}\text { Links with university } \\
\text { only (linkonlyUn) }\end{array}$ & & $\begin{array}{l}-0.287^{*} \\
(0.217)\end{array}$ & & $\begin{array}{c}-0.415 * * \\
(0.177) \\
\end{array}$ & & $\begin{array}{l}0.204 * \\
(0.144)\end{array}$ & & $\begin{array}{c}1.039 * * * \\
(0.211)\end{array}$ & & & \\
\hline $\begin{array}{l}\text { Duration of links } \\
\text { (TIME) }\end{array}$ & & & & & & & & & $\begin{array}{c}0.231 \\
(0.249) \\
\end{array}$ & $\begin{array}{c}0.549 * * \\
(0.277)\end{array}$ & $\begin{array}{c}(-0.302) \\
(0.325)\end{array}$ \\
\hline cons & $\begin{array}{l}-0.069 \\
(0.425)\end{array}$ & $\begin{array}{l}0.439 * \\
(0.277)\end{array}$ & $\begin{array}{l}-0.019 \\
(0.463)\end{array}$ & $\begin{array}{c}0.043 \\
(0.501)\end{array}$ & $\begin{array}{c}0.133 \\
(0.423) \\
\end{array}$ & $\begin{array}{l}-0.141 \\
(0.201)\end{array}$ & $\begin{array}{l}-0.095 \\
(0.445)\end{array}$ & $\begin{array}{c}-0.662 * * \\
(0.268)\end{array}$ & $\begin{array}{l}-0.388^{*} \\
(0.242)\end{array}$ & $\begin{array}{l}-0.202 \\
(0.268)\end{array}$ & $\begin{array}{l}(0.365) \\
(0.315)\end{array}$ \\
\hline Observations & & 310 & & 310 & & 310 & & 310 & & & \\
\hline Censored & & 69 & & 69 & & 69 & & 69 & & & \\
\hline Wald Chi2(15) & & 19.66 & & 40.76 & & 20.11 & & 30.71 & & & \\
\hline Prob>chi2 & & 0.003 & & 0.000 & & 0.002 & & 0.000 & & & \\
\hline athrho & & -0.654 & & -0.443 & & -0.902 & & -0.553 & & & \\
\hline Insigma & & 0.013 & & -0.038 & & 0.071 & & -0.028 & & & \\
\hline rho & & -0.575 & & -0.416 & & -0.717 & & -0.503 & & & \\
\hline sigma & & 1.013 & & 0.963 & & 1.074 & & 0.973 & & & \\
\hline lambda & & -0.582 & & -0.401 & & -0.770 & & -0.489 & & & \\
\hline $\begin{array}{l}\text { Wald test of indep. eqns. } \\
(\text { rho }=0) \text { : }\end{array}$ & & 10.9 & & 0.28 & & 22.61 & & 4.32 & & & \\
\hline
\end{tabular}


According to the results for firms in our sample, at stage one, behavioral factors related to R\&D activities (innovation capabilities and innovation strategy) are more important drivers for interaction than are structural factors related to firm size (Cohen, et al., 2002; Santoro and Chakrabarti, 2002; and Hanel and St-Pierre, 2006) or sector (Laursen and Salter, 2004; Hanel and St-Pierre, 2006; Segarra-Blasco and Arauzo-Carod, 2008; and Tether and Tajar, 2008) and to ownership. On the other hand, our results confirm those by Laursen and Salter (2004), Eom and Lee (2009), Torres, et al. (2011) and Dutrénit, et al. (2010a), who hold that the most important drivers are innovation capabilities (formalization of $\mathrm{R} \& \mathrm{D}$ activities), followed in our case by innovation strategy (openness strategy related to access to open information, consulting and research projects with other firms, suppliers, market, and fiscal incentives for R\&D). Even though the significance of fiscal incentives for R\&D as drivers of collaboration is not strong in our case (only 10\%), it is in line with those results obtained by Segarra-Blasco and Arauzo-Carod (2008) and Bekkers and Bodas-Freitas (2010), who found that access to public funds for R\&D activities is an important determinant of collaboration.

Results from equations (1.2.1), (1.2.2), (1.2.3), and (1.2.4) suggest that behavioral factors of the firms in our sample are important determinants of channels of interaction, and that each explanatory variable has a different impact on each type of channel. Fiscal incentives for R\&D constitute an important determinant for IPRChannel, which suggests that policy programs to stimulate private $R \& D$ are successfully promoting patenting, a very rare activity among Mexican firms. With a less robust coefficient, fiscal incentives also have a positive impact on the ProjectChannel; this indicates that the use of fiscal incentives for R\&D encourages PRO-I interaction through specific research projects, thus contributing to a virtual circle of the creation and diffusion of knowledge. The negative significance of fiscal incentives on the HRChannel might indicate that firms that are granted such incentives prefer to use highly skilled human resources to perform complex projects rather than hiring recent graduates. There seems to be a pattern in terms of the type of PRO and the preferred channel of interaction. Linking with universities promotes the use of HRChannel and the IPRChannel, while linking with PRO promotes the use of ProjectChannel and InfoChannel. Linking with both universities and centers promotes the use of ProjectChannel and HRChannel. Some behavioral channels showed an impact on PRO-I interaction at a lower level. Nationally owned firms tend to use the InfoChannel and the IPRChannel more actively; firms with foreign investment do not tend to use these channels as much as nationally owned firms, probably as a result of their privileged access to foreign technologies at headquarters or their interactions with foreign PRO.

Regarding benefits from interaction, several authors argue that different channels of interaction have a positive effect on benefits perceived by researchers and firms (Wright, 2008; Arza, 2010). From equations (1.3.1), (1.3.2), and (1.3.3), we found that the four channels of interaction are important ways of obtaining benefits from collaboration, but they have different impacts on each type of benefit. Regarding RDCapB benefits, the important channels are ProjectChannel, followed by IPRChannel and HRChannel. These results are similar to those of Adams, et al. (2003), Arvanitis, et al. (2008), and Dutrénit, et al. (2010a), who found that PRO-I interactions through R\&D, yield increases in innovation and productivity. This has a positive impact on innovation activities, as firms 
engage in more formal R\&D activities with PRO. R\&D intensity, as measured through human resources in $\mathrm{R} \& \mathrm{D}$, is an important determinant for RDCapB benefits, which is in line with the results of Bishop, et al. (2011). Regarding the non-RDCapB benefits, we found that the HRChannel and the duration of linkages are significant and important determinants. Interaction through the hiring of recent graduates plays a key role in increasing firms' absorptive capacities through non-R\&D mechanisms (Cohen, et al., 2002; Bishop, et al., 2011). As for the Quality Benefits, we found that the InfoChannel is an important determinant. These results, which underscore the fact that each type of channel of interaction has different impacts on benefits from collaboration, contribute to the results of Dutrénit, et al. (2010a), Arza and Vazquez (2010), Fernandes, et al. (2010), and Orozco and Ruíz (2010).

\subsection{Researchers}

Table 7 presents the results of the regression model for equations (2.1), (2.2.1), (2.2.2), (2.2.3), (2.2.4), (2.3.1), and (2.3.2) for researchers. As with the model for firms, we

observe that the coefficients of the four different selection equations (2.1) do not vary greatly, and that Prob $>\mathrm{chi}^{2}$ is significant in the four equations for channels of interaction. Hence, the results of these equations reflect a robust Heckman model. 
Table 7 Regression models for researchers

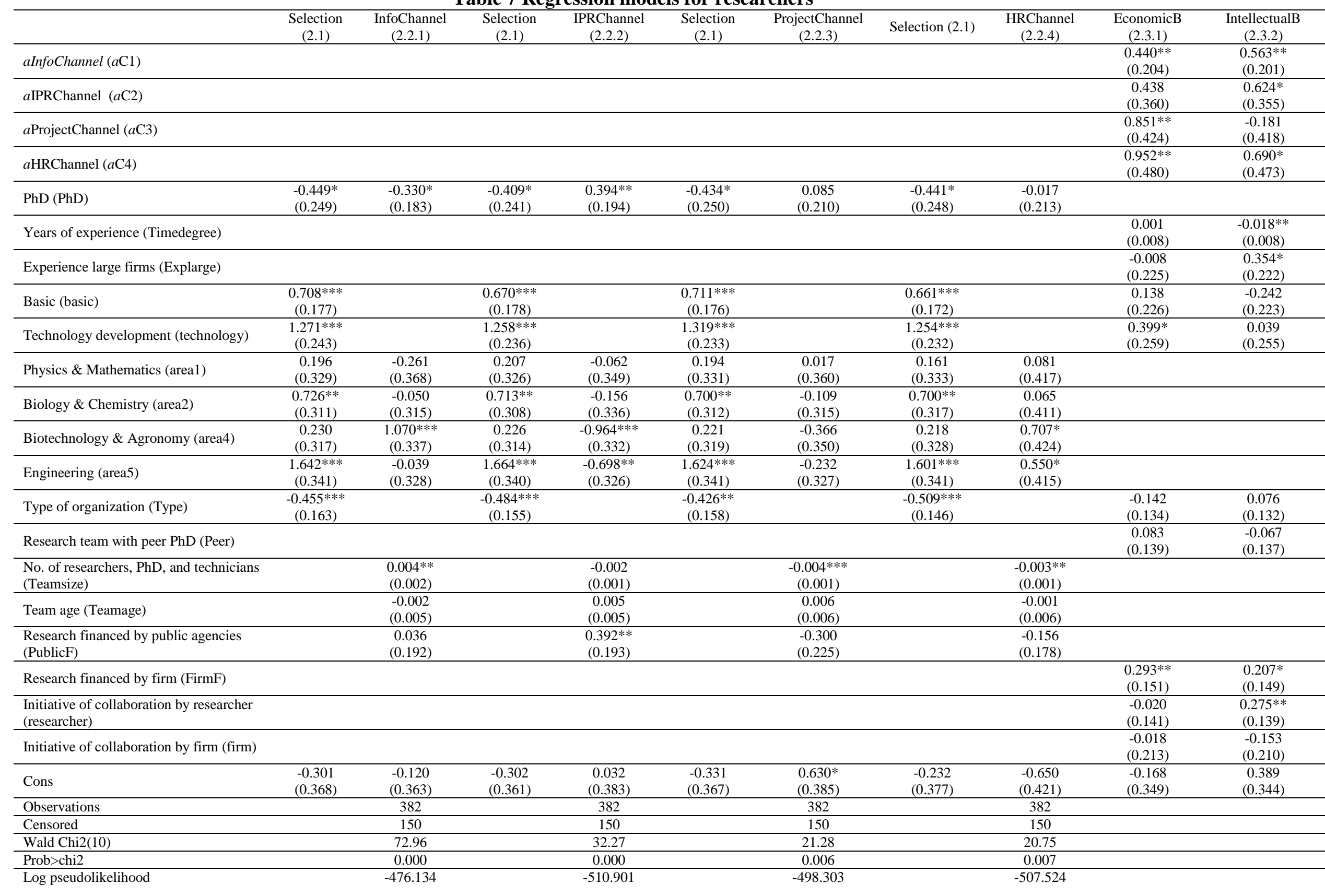




\begin{tabular}{|c|c|c|c|c|}
\hline athrho & 0.234 & -0.485 & -0.344 & 0.749 \\
\hline lnsigma & -0.155 & 0.030 & -0.047 & 0.067 \\
\hline Rho & 0.230 & -0.450 & -0.331 & 0.635 \\
\hline sigma & 0.856 & 1.030 & 0.954 & 1.070 \\
\hline lambda & 0.197 & -0.464 & -0.316 & 0.679 \\
\hline Wald test of indep. eqns. $($ rho $=0)$ : & 1.29 & 6.260 & 2.270 & 11.570 \\
\hline
\end{tabular}


From the researchers' perspective, results from our sample confirm findings by other authors regarding determinants for interaction. For instance, we found that individual factors such as type of research, research field (Friedman and Silverman, 2003; Bercovitz and Feldman, 2003; D'Este and Patel, 2007; Jensen, et al., 2008; Bekkers and Bodas Freitas, 2008; Boardman and Ponomariov, 2009) and degree, and institutional factors such as institutional affiliation (Boardman and Ponomariov, 2009), are important determinants of collaboration. However, some differences arise in our sample of Mexican researchers. Researchers without postgraduate degrees and those working in centers are more likely to connect with industry than otherwise, and researchers who carry out basic research and technology development tend to connect more than those who carry out applied research. These results confirm those found by Dutrénit, et al. (2010a); hence we argue that this is quite specific to the Mexican case, as the incentives structure (National Researchers System program) and the scarcity of resources seem to stimulate researchers doing basic science to interact with industry, particularly by accessing public funds that foster PRO-I interaction. Our results also show that researchers in certain knowledge areas, such as Biology \& Chemistry and Engineering, tend to collaborate much more than those from Medicine \& Health Sciences. These results seem to complement those found by Dutrénit, et al. (2010a) and Arza and Vazquez (2010), as, according to their findings, researchers from Biotechnology \& Agronomy tend to connect more than those in Physics \& Mathematics. The latter is in line with the ideas of the Pasteur quadrant proposed by Stokes (1997).

Regarding the second stage of the linking process, we found that researchers in Biotechnology \& Agronomy tend to use the InfoChannel much more than researchers from Medicine \& Health Sciences. This confirms the results by Cohen, et al. (2002), as publications, which are one form of interaction included in the InfoChannel, are particularly important for Biotechnology. With regard to the IPRChannel, we found that public research grants and researchers with $\mathrm{PhD}$ degrees are important determinants for fostering this channel. Bolli and Somogyi (2011) obtained similar results and argue that channels of interaction are stimulated by different types of funding. In our case, public financing fosters the IPRChannel. Fields of knowledge also seem to play a key role, as Medicine \& Health Sciences tend to use this channel more than do Biotechnology \& Agronomy or Engineering. This finding complements the results obtained by Schartinger, et al. (2002), who argue that knowledge flows through patents are particularly important for Chemistry. We found that, for researchers in our sample, the size of the research group - and in particular small team size - is an important determinant for the ProjectChannel and the HRChannel, since interaction within the group tends to be more focused if the group is small; moreover, it may involve the more complex forms of knowledge that are required for carrying out R\&D projects with industry.

From equations (2.3.1) and (2.3.2) we found that the four channels of interaction are important determinants for obtaining benefits from collaboration, but they have different impacts on each type of benefit. Regarding economic benefits, our results suggest that the InfoChannel, ProjectChannel, and HRChannel have a positive impact on economic benefits. The ProjectChannel is most likely to play an important role if research is financed by firms. These results are in line with those by Wright et al. (2008), who found that contract research has an important effect on university royalties. The IPRChannel does not represent a significant 
determinant of economic benefits for researchers, and it only slightly impacts intellectual benefits, which suggests that neither group derives much economic or intellectual benefit from this channel; this argument has important policy implications, as a major goal of innovation policy is to increase patenting activity in Mexico. However, this result requires further research in the Mexican context. Other less important determinants are related to the type of research, with researchers who perform technology development being more inclined to obtain economic benefits; similar results were obtained by Dutrénit, et al. (2010a). Regarding intellectual benefits, only the InfoChannel has a strong and positive impact on the researchers in our sample. The ProjectChannel and the HRChannel have less of an impact on intellectual benefits. However, we did not find the ProjectChannel to be an important determinant of intellectual benefits, which partially contradicts Wright et al. (2008) and Dutrénit, et al. (2010a), who found that the ProjectChannel does bring intellectual benefits to researchers. Other individual factors also have an important role in obtaining benefits from collaboration; young researchers who initiate the collaboration process tend to obtain more intellectual benefits than those who don't. These results confirm those of Bekkers and Bodas Freitas (2010) and Jensen, et al. (2008), and complement those of Giuliani, et al. (2010), who found that younger researchers tend to establish more PRO-I linkages. On the other hand, Wigren et al. (2011) make an argument that moresenior researchers in Sweden have a greater amount of research time and are more active in diffusing and commercializing their research results. It is important to note that collaboration initiated by firms does not seem to play an important role in perceived benefits; however, collaboration financed by firms does bring economic benefits to researchers.

\subsection{Connecting the behavior of firms and researchers through channels of interaction}

Previous studies that focus on the analysis of PRO-I interaction from the PRO perspective have contributed to an understanding of the process of knowledge transfer and, to a lesser extent, its impact on firms' innovation activities (Vessuri, 1998; Casas, et al., 2000; Cohen, et al., 2002; Arocena and Sutz, 2005; Albuquerque, et al., 2008; Bekkers and Bodas Freitas, 2008; Maculan and Carvalho, 2009; Perkmann and Walsh, 2009; Cassiman, et al., 2010). It is recognized that, during the collaboration process, researchers derive economic and intellectual benefits. In fact, as researchers derive more benefits from interaction, they support collaboration with industry more actively. This paper contributes to the literature by exploring the connection between firms' benefits and researchers' characteristics. We make this connection by exploring their behavior in relation to the use of channels of interaction and by identifying which channels produce the most long-term benefits for firms, and which researchers characteristics best explain the use of these channels.

As shown in table 6, main benefits that firms derive from interaction are related to the strengthening of capabilities through $R \& D$, the strengthening of capabilities through other innovation activities, and improvements in quality. The benefits to firms range from short to long-term benefits. Short-term benefits are associated with increases in quality, while long-term benefits are related to the strengthening of capabilities through $R \& D$ and on innovation activities other than R\&D. In other words, long-term benefits are associated with an increase in knowledge 
content that leads to new ideas for research projects or with an increase in absorptive capabilities by firms (Cohen and Levinthal, 1999).

By connecting long-term benefits for firms and researchers characteristics through the use of the same channels of interaction, we found that the four channels yield positive benefits for PRO and firms (fig. 1). However, the best channels - i.e. those associated with long-term benefits for firms - are the ProjectChannel, the IPRChannel, and the HRChannel. This is due to their potential to generate innovations (Rosenberg and Nelson, 1994). The HRChannel also has significant results for other long-term benefits for firms related to strengthening capabilities based on other innovation activities that are not based on $R \& D$, which also lays the ground for strengthening absorptive capacities and the possibility of engaging in future successful collaboration with PRO (Swann, 2002; Cohen, et al., 2002; Wright, 2008). In contrast, the InfoChannel brings only shortterm benefits for firms.

Figure 1 Connection between researchers' and firms' benefits through channels of interaction

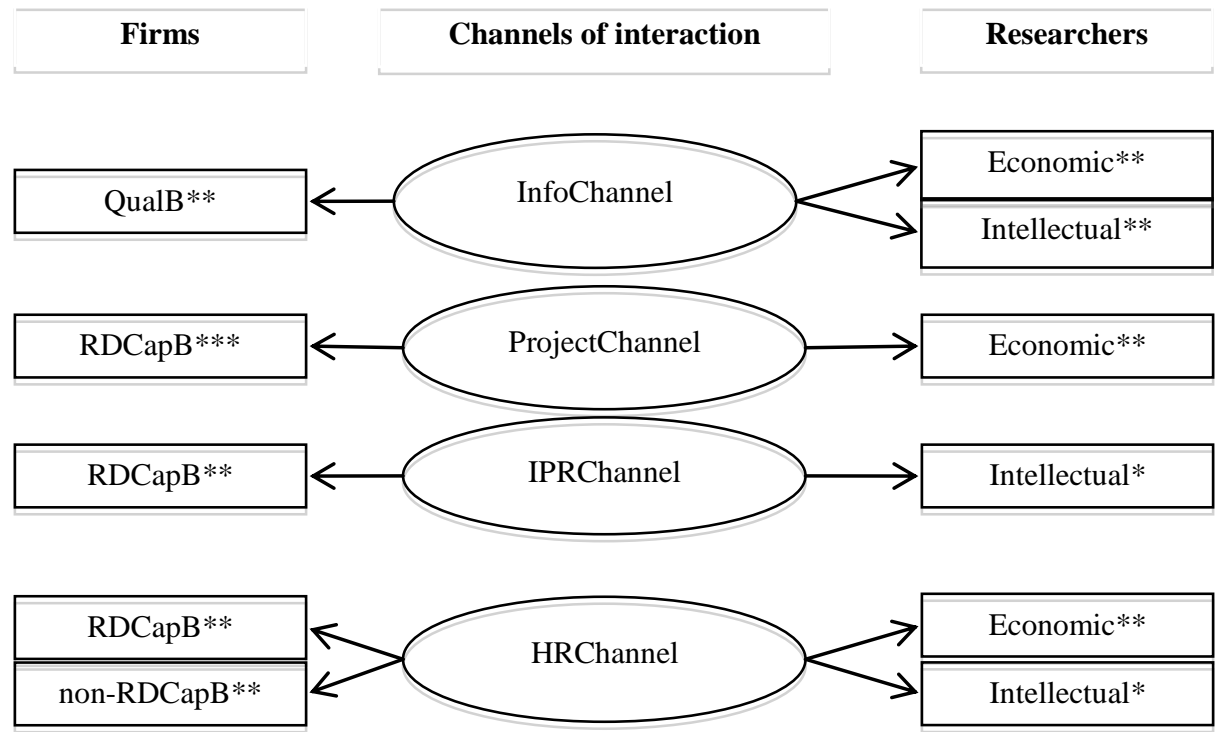

Note: Significance level from tables 6 and 7

$* \mathrm{p}<0.1 ; * * \mathrm{p}<0.05 ; * * * \mathrm{p}<0.005$

Regarding the three channels that may contribute to long-term benefits for firms, it is important to look at the specific researchers characteristics, which drive their use, as well as the characteristics of the firms. Figure 2 shows the specific characteristics of researchers and firms that affect channels of interaction.

Figure 2 Characteristics of researchers and firms that affect the best channels of interaction

\begin{tabular}{ccc}
\hline Channel & Researchers characteristics & \multicolumn{1}{c}{ Firms characteristics } \\
\hline ProjectChannel & -No. of researchers $*$ & Fiscal incentives * \\
\hline
\end{tabular}




\begin{tabular}{|c|c|c|}
\hline & & $\begin{array}{l}\text { Links with both } * \\
\text { Links only centers } * * *\end{array}$ \\
\hline IPRChannel & $\begin{array}{l}\text { PhD** } \\
\text {-Biotechnology area4*** } \\
\text {-Engineering area5** } \\
\text { Public financing } * *\end{array}$ & $\begin{array}{l}\text { Ownership (i.e., national)* } \\
\text { Fiscal incentives } * * * \\
\text { Links only with universities } *\end{array}$ \\
\hline HRChannel & $\begin{array}{l}\text { Biotechnology area4* } \\
\text { Engineering area5* } \\
\text {-No. of researchers } * *\end{array}$ & $\begin{array}{l}\text {-Fiscal incentives* } \\
\text { Links with both } * * * \\
\text { Links only with universities } * * *\end{array}$ \\
\hline
\end{tabular}

Concerning researchers characteristics in our sample, those that turned out to be the most important for the channels that generate the best benefits for firms - i.e., lng-term benefits where the number of researchers, whether they hold a $\mathrm{PhD}$ degree, and whether they access public funding; some areas of knowledge also have an impact on those same channels. We found a negative relationship between the number of researchers on the team and the likelihood of interactions being established through the ProjectChannel and HRChannel. This result indicates that one of the researchers characteristics that foster these channels is belonging to small research groups which are well integrated and focused on specific problems.

Researchers who hold PhD degrees in Medicine \& Health Sciences rather than in Biotechnology \& Agronomy or Engineering tend to connect more through the IPRChannel. Schartinger, et al. (2002) and Balconi and Laboranti (2006) also found that certain areas of knowledge tend to use this particular channel of interaction; however, in their study the areas were electronics and biotechnology. Our results also suggest that public financing granted to researchers in our sample stimulates the use of this channel, which has direct policy implications.

HRChannel has been identified as one of the most important channels during PRO-I interaction (Narin, et al., 1997; Swann, 2002; Cohen, et al., 2002; Meyer-Krahmer and Schmoch, 1998; Mowery and Sampat, 2005; D’Este and Patel, 2007; Perkmann and Walsh, 2009; Dutrénit, et al, 2010). The researchers characteristic that most strongly promotes this channel is membership in small research groups. Knowledge fields from Biotechnology \& Agronomy and from Engineering also promote this channel, but at a lower level, which is in line with the findings of Schartinger, et al. (2002) and Balconi and Laboranti (2006) regarding differences by knowledge areas.

Concerning the characteristics of firms, fiscal incentives for R\&D, and links with universities or centers were shown to be important for those channels that generate the best benefits for firms i.e., long-term. To foster ProjectChannel, firms prefer to interact either with centers rather than with universities, or with both types of organizations at the same time, in order to focus more on technology development and applied research than on basic research. This result confirms those by Boardman and Ponomariov (2009), as they argue that researchers in centers are more eager to interact than are researchers from universities. Centers in Mexico are usually project-oriented and have had increasing motivation to perform applied research in collaboration with firms. 
Fiscal incentives for R\&D have been shown to have some positive impact on this channel from the firms' perspective; however, it seems necessary to identify fiscal incentives that could be better taken advantage of by more innovative firms.

Our results regarding the IPRChannel suggest that, in order to stimulate this channel, it is important to promote fiscal incentives, as there is a strong association between having benefited from fiscal incentives for R\&D and the use of this channel. In fact, this public program looks upon patenting as an expected result of providing such fiscal benefits. This result suggests that some of the objectives of the program are being accomplished. National ownership, and linking only with universities, stimulate this channel to a lesser degree.

To stimulate the HRChannel, firms would prefer to connect with universities only, or with universities and centers at the same time. Even though the significance is low, we determined that fiscal incentives for R\&D play a negative role in achieving this type of benefit, which might be related to the fact that firms prefer to connect through the ProjectChannel if they have access to fiscal incentives; the hiring of recent graduates is not a priority, as firms need human resources with research experience to perform specific projects.

Overall, our evidence suggests that firms prefer to collaborate with centers and universities to strengthen $R \& D$ capabilities based on $R \& D$ and capabilities based on innovation activities other than R\&D. The main researchers characteristics that foster this type of long-term benefit for firms are related to the characteristics of individuals $(\mathrm{PhD}$ degree, areas of knowledge, and size of research team), and to institutional characteristics (access to public funds). Thus, researchers from Biotechnology \& Agronomy and Engineering who work in small teams and have pubic funding promote long-term benefits. The main firms characteristics that reinforce these benefits are related to behavioral and structural characteristics, such as links with universities, links with centers, and fiscal incentives.

\section{Conclusions}

This paper contributes to the present discussion of PRO-I interaction by connecting firms' benefits and researchers' characteristics through four channels of interaction and identifying the best channels for the long-term benefits of firms. We do so by proposing a methodology to analyze three stages of the linking process for researchers and for firms individually; we then connect both results and test that outcome with two samples of firms and researchers.

We argue that the best channels of interaction are those that contribute to firms obtaining longterm benefits. For the samples of firms and researchers included in this study, we found that the ProjectChannel, IPRChannel, and HRChannel play a key role in increasing firms' capabilities based on $R \& D$ and on innovation activities other than $R \& D$. This is in line with the results of Rosenberg and Nelson (1994), Lee (2000) and Cohen, et al. (2002) regarding the importance of developing new products, and of Zucker et al. (2002), Adams, et al. (2003), Hanel and St-Pierre (2006), Arvanitis, et al. (2008), Eom and Lee (2010) and Bishop et al. (2011) regarding the importance of increasing innovative and $R \& D$ capabilities. In contrast, the InfoChannel is 
important only for short-term benefits associated with quality control, as argued by Arza (2010) and Bishop et al. (2011).

The main characteristics of researchers that foster long-term benefits for firms are related to individual and institutional characteristics, such as degree, field of knowledge, size of research team, and the acquisition of public financing for research. More specifically, researchers who have $\mathrm{PhD}$ degrees, collaborate academically in small research teams, and work in certain fields of knowledge - which might vary according to the channel of interaction - are more likely to have a potential impact on the long-term benefits of firms. Public financing granted to researchers also has a positive impact on the long-term benefits for firms.

Based on both researchers' and firms' characteristics, we have gained insights into the specific determinants that strengthen different channels of PRO-I interaction, which yields several challenges for policy. Concerning the ProjectChannel, sources of public funding should identify the best small research groups in centers that are more inclined to connect with others, and also should introduce new schemes for fiscal incentives for $R \& D$, as firms that benefited from this program tend to use this channel more. With regard to fostering the IPRChannel in order to contribute to long-term benefits for firms, our results suggest that public policy should focus on supporting those researchers that who PhDs in key areas - e.g., Medicine \& Health Sciences. It is also important to encourage patenting within the scheme of PRO-I collaboration, with careful definition of the ownership of the patent. Relating to the HRChannel, encouraging interaction with small research groups from Biotechnology \& Agronomy and Engineering might have positive effects.

Some other conclusions regarding the three stages of the linking process suggest that, during the interaction process, some differences in the importance of the factors emerge, and these also have policy implications. Concerning the drivers of interaction, researchers without $\mathrm{PhD}$ degrees tend to interact more than PhD holders, but once the interaction has started, researchers with postgraduate degrees use those channels of interaction that have a positive effect on long-term benefits for firms. Thus it is important to find the right stimulus within the National Researcher System for PhD holders who promote successful interaction. Researchers affiliated with centers tend to interact more than researchers who are affiliated with universities; the challenge here for policy is threefold: to design specific stimulus within the National Researcher System in order to promote the interaction of university researchers; to create and strengthen technology transfer offices at universities; and to design programs to stimulate interactions targeted at researchers affiliated with research centers.

Regarding benefits, our results confirm that researchers are interested in receiving both economic and intellectual benefits (Meyer-Krahmer and Schmoch, 1998; Lee, 2000; Welsh, et al., 2008; Perkmann and Walsh, 2009), and that firms are interested in long-term benefits to perform research projects and increase absorptive capabilities (Adams, et al., 2003; Arvanitis, et al., 2008). This indicates the importance of creating programs to foster ProjectChannel, IPRChannel, and HRChannel during PRO-I collaboration, as these channels contribute to benefits for both agents. From the researchers' perspective, we found that other variables related to individual 
factors are important determinants of benefits, which indicate that collaboration is based on trust. One of the mechanisms for building trust among agents is the creation of informal spaces for interaction, which might contribute to enhanced benefits, as has been argued by Wright, et al. (2008), D’Este and Perkmann (2010), and Sá and Litwin (2011).

Summing up, this paper makes the argument that in order to strengthen firms' innovative linkages, policymakers should put emphasis on promoting researchers' and firms' characteristics related to different forms of interaction while looking for the best articulation of the supply and demand of knowledge - i.e., the best channels of interaction for firms. The designing of creative policies to encourage the mutual reinforcement of interaction and long-term benefits is required. In the Mexican case, policies to encourage channels of interaction from the researchers' perspective require a rethinking of the structure of the National Researcher System, with an eye to promoting interaction, recognizing the importance of collaboration with industry, and promoting incentives for researchers who actually collaborate. If the National Researcher System would promote the creation and consolidation of small research groups with more focused activities, it could contribute in that direction. Policies to encourage channels of collaboration from the firms' perspective should take into account the design of fiscal incentives for R\&D targeted at national firms and should emphasize the importance of research and collaboration on certain fields of knowledge, such as Medicine \& Health Science, Biotechnology \& Agronomy, and Engineering.

Policy-makers should also be attentive to possible tangential effects derived from policies not designed specifically to encourage PRO-I interactions. An example of this is, again, the program of fiscal incentives for R\&D, an instrument that has helped to foster PRO-I interactions. Learning through interaction may have been a by-product of this program, thus showing the potential benefits that could be obtained from that relationship. Policy instruments such as this may help to overcome barriers to interaction, but the analysis of those impacts requires further investigation. This study has also identified some barriers that fiscal incentives have imposed on certain channels of interaction, such as the HRChannel. Encouraging firms that apply for fiscal incentives for R\&D to hire recent graduates may provide improved results for innovation in this context.

Finally, this paper is based on large samples of firms and researchers. Further research might test the methodology and the findings using more complete databases for researchers and firms at a broader national level. 


\section{Appendix}

Table A.1 Channels of interaction: Firms

\begin{tabular}{lcccc}
\hline \multicolumn{1}{c}{ Component } & $\begin{array}{c}\text { Channel 1. } \\
\text { Information } \\
\text { \& Training }\end{array}$ & $\begin{array}{c}\text { Channel 2. } \\
\text { R\&D } \\
\text { Projects \& } \\
\text { Consultancy }\end{array}$ & $\begin{array}{c}\text { Channel 3. } \\
\text { Property } \\
\text { rights }\end{array}$ & $\begin{array}{c}\text { Channel 4. } \\
\text { HR }\end{array}$ \\
\hline Publications & 0.747 & 0.192 & 0.465 & 0.083 \\
Conferences & 0.761 & 0.303 & 0.322 & 0.175 \\
Informal information & 0.697 & 0.459 & 0.011 & 0.236 \\
Training & 0.519 & 0.225 & 0.48 & 0.376 \\
Contract R\&D & 0.261 & 0.820 & 0.275 & 0.215 \\
Consultancy & 0.415 & 0.605 & 0.455 & 0.262 \\
Joint R\&D & 0.317 & 0.808 & 0.308 & 0.168 \\
Technology licenses & 0.307 & 0.351 & 0.757 & 0.283 \\
Patents & 0.233 & 0.301 & 0.822 & 0.235 \\
Hiring of students & 0.221 & 0.194 & 0.287 & 0.699 \\
\hline
\end{tabular}

Extraction Method: Principal Factor Analysis

Rotation Method: Varimax with Kaiser Normalization

Rotation converged in 3 iterations

Explained variance: $76.9 \%$

Table A.2 Channels of interaction: Researchers

\begin{tabular}{lcccc}
\hline \multicolumn{1}{c}{ Component } & $\begin{array}{c}\text { Channel 1. } \\
\text { Information } \\
\text { \& training } \\
\text { (InfoChannel) }\end{array}$ & $\begin{array}{c}\text { Channel 2. } \\
\text { Property } \\
\text { rights } \\
\text { (IPRChannel) }\end{array}$ & $\begin{array}{c}\text { Channel 3. R\&D } \\
\text { Projects and } \\
\text { Consultancy } \\
\text { (ProjectChannel) }\end{array}$ & $\begin{array}{c}\text { Channel 4. } \\
\text { HR } \\
\text { (HRChannel) }\end{array}$ \\
\hline Publications & .675 & .393 & .343 & .180 \\
Conferences & .852 & .074 & .103 & .202 \\
Informal information & .743 & .229 & .309 & .050 \\
Training & .586 & .361 & .452 & .185 \\
Technology licenses & .230 & .854 & .241 & .153 \\
Patents & .192 & .855 & .209 & .204 \\
Contract R\&D & .202 & .216 & .770 & .290 \\
Consultancy & .237 & .174 & .800 & .067 \\
Joint R\&D & .388 & .416 & .529 & .076 \\
Hiring of students & .255 & .280 & .237 & .877 \\
\hline
\end{tabular}

Extraction Method: Principal Factor Analysis

Rotation Method: Varimax with Kaiser Normalization

Rotation converged in 3 iterations

Explained variance: $77.4 \%$ 
Table A.3 Firms' benefits: Rotated Component Matrix

\begin{tabular}{lccc}
\hline & RDCapB & $\begin{array}{c}\text { non- } \\
\text { RDCapB }\end{array}$ & QualB \\
\hline Technology transfer & 0.5232 & 0.5262 & 0.2061 \\
Technology advice and consultancy to solve & 0.4561 & 0.5902 & 0.3561 \\
production problems & 0.4992 & 0.5118 & 0.3234 \\
To increase firms' absorptive capacities & 0.3771 & 0.5854 & 0.3655 \\
Information about technology forecast & 0.4083 & 0.4965 & 0.2453 \\
Hiring of human resources & 0.7406 & 0.3844 & 0.253 \\
Joint R\&D & 0.7358 & 0.3544 & 0.312 \\
Contract R\&D & 0.7397 & 0.2812 & 0.3843 \\
To use PRO facilities & 0.572 & 0.2983 & 0.5781 \\
To perform tests for products and process & 0.4619 & 0.3249 & 0.5595 \\
Quality control & & & \\
\hline
\end{tabular}

Extraction Method: Principal Factors Analysis

Rotation Method: Varimax with Kaiser Normalization

Rotation converged in 3 iterations

Explained variance: $62.2 \%$

Table A.4 Researchers' benefits: Rotated Component Matrix

\begin{tabular}{lcc}
\hline & Intellectual & Economic \\
\hline Further collaboration projects & 0.900 & 0.184 \\
Ideas for further research & 0.802 & 0.352 \\
Knowledge/information sharing & 0.754 & 0.324 \\
Reputation & 0.653 & 0.408 \\
Shared equipment/instruments & 0.319 & 0.696 \\
Provision of research inputs & 0.320 & 0.803 \\
Financial resources & 0.216 & 0.797 \\
\hline
\end{tabular}

Extraction Method: Principal Component Analysis

Rotation Method: Varimax with Kaiser Normalization

Rotation converged in 3 iterations

Explained variance: $69.8 \%$ 
Table A.5 Firms' openness strategy: Rotated Component Matrix

\begin{tabular}{lcccc}
\hline \multicolumn{1}{c}{ Linkages } & $\begin{array}{c}\text { Access to } \\
\text { open science }\end{array}$ & $\begin{array}{c}\text { Consulting } \\
\text { and research } \\
\text { projects with } \\
\text { other firms }\end{array}$ & Market & Suppliers \\
\hline Suppliers & .183 & .142 & .076 & .911 \\
Customers & .061 & .024 & .876 & .137 \\
Competitors & .433 & .182 & .509 & -.226 \\
Joint or cooperative projects with & .114 & .626 & .365 & .165 \\
other firms & .016 & .849 & -.076 & .059 \\
Consultancy with R\&D firms & .603 & .449 & .090 & -.095 \\
Publications and technical reports & .693 & -.088 & .204 & .119 \\
Expos & .773 & .090 & -.011 & .222 \\
Internet & & & & \\
\hline Extractin
\end{tabular}

Extraction Method: Principal Component Analysis

Rotation Method: Varimax with Kaiser Normalization

Rotation converged in 3 iterations

Explained variance: $66.1 \%$ 


\section{Acknowledgements}

The authors would like to thank Pierre Mohnen for providing useful comments. Financial support for this project was received from IDRC and CONACYT (Mexico). We thank the two anonymous reviewers for their insightful comments, which helped focus the contribution of this work.

\section{References}

Adams, J. D., Chiang, E. P., Jensen, J. L., 2003. The influence of federal laboratory R\&D on industrial research. Review of Economics and Statistics. 85(4), 1003-1320.

Albuquerque, E., Suzigan, W., Cário, S., Fernandes, A., Shima, W., Britt, J., 2008. An investigation on the contribution of universities and research institutes for maturing the Brazilian innovation system: Preliminary Results. Paper presented at the Globelics Conference, Mexico City.

Arocena, R., Sutz, J., 2005. Latin American Universities: From an original revolution to an uncertain transition. Higher Education. 50, 573-592.

Arvanitis S., Kubli, U., Woerter, M., 2008. University-Industry knowledge and technology transfer in Switzerland: What university scientists think about co-operation with private enterprises. Research Policy. 37, 1865-1883.

Arza, V., 2010. Channels, benefits and risks of public-private interactions for knowledge transfer: A conceptual framework inspired by Latin America. Science and Public Policy. 37(7), 473-484.

Arza, V., Vazquez, C., 2010. Interactions between public research organisations and industry in Argentina: Analysis of channels and benefits for researchers and firms. Science and Public Policy. 37(7), 499-511.

Asheim, B., Coenen, L., 2005. Knowledge bases and Regional Innovation Systems: Comparing Nordic Clusters. Research Policy. 34, 1173-1190.

Ayadi, M., Rahmouni, M., Yildizoglu, M., 2009. Determinants of the innovation propensity in Tunisia: The central role of external knowledge sources. Working papers halshs- 00368560 .

Balconi, M., Laboranti, A., 2006. University-industry interactions in applied research: The case of microelectronics. Research Policy. 35(10), 1616-1630.

Bekkers, R., Bodas Freitas, I., 2008. Analysing knowledge transfer channels between universities and industry: To what degree do sectors also matter? Research Policy. 37, 1837-1853.

Bekkers, R., Bodas-Freitas, I., 2010. Catalyst and barriers: Factors that affect the performance of university-industry collaborations. Conference paper International Schumpeter Society Conference 2010.

Bercovitz, J., Feldman M., 2003. Technology transfer and the academic department: Who participates and why? Conference paper DRUID Summer Conference, Copenhagen, Denmark, 2003.

Bishop, K., D’Este, P., Neely, A., 2011. Gaining from interactions with universities: Multiple methods for nurturing absorptive capacity. Research Policy. 40(1), 30-40.

Boardman, P.C., Ponomariov, B.L., 2009. University researchers working with private companies. Technovation. 29, 142-153.

Bolli, T., Somogyi, F., 2011. Do competitively acquired funds induce universities to increase productivity? Research Policy. 40, 136-147.

Bozeman, B., Corley, E., 2004. Scientists' collaboration strategies: Implications for scientific and technical human capital. Research Policy. 33, 599-616.

Bozeman, B., Gaughan, M., 2007. Impacts of grants and contracts on academic researchers' interactions with industry. Research Policy. 36, 694-707.

Broström, A., 2010. Working with distant researchers: Distance and content in university-industry interaction. Research Policy. 39(10), 1311-1320. 
Carayol, N., 2004. Objectives, agreements and matching in science-industry collaborations: Reassembling the pieces of the puzzle. Research Policy. 32, 887-908.

Casas, R., de Gortari, R., Luna, M., 2000. University, knowledge production and collaborative patterns with industry, in: Cimoli, M. (Ed.), Developing Innovation Systems: Mexico in a Global Context. Continuum, London.

Cassiman, B., Di Guardo, M. C., Valentini, G., 2010. Organizing links with science: Cooperate or contract?: A project-level analysis. Research Policy. 39(7), 882-892.

Cassiolato, J. E., Lastres, H., Maciel, M. L. (Eds.), 2003. Systems of Innovation and Development. Evidence from Brazil. Cheltenham, Edward Elgar, UK.

Cimoli, M. (Ed.), 2000. Developing Innovation Systems: Mexico in a Global Context. Continuum, London.

Cohen, W., Levinthal, D. 1999. Absorptive capacity: A new perspective on learning and innovation. Administrative Science Quarterly. 35(1), 128-152.

Cohen, W., Nelson, R., Walsh, J., 2002. Links and Impacts: The influence of public research on industrial R\&D. Management Science. 48(1), 1-23.

Colyvas, J., Crow, M., Gelijns, A., Mazzoleni, R., Nelson, R., Rosenberg, N., Sampat, B. N., 2002. How do university inventions get into practice? Management Science. 48 (1), 61-72.

Crépon, B., Duguet, E., Mairesse, J., 1998. Research, innovation and productivity: An econometric analysis at the firm level. National Bureau of Economic Research, Cambridge, MA.

D'Este, P., Patel, P., 2007. University-industry linkages in the UK: What are the factors underlying the variety of interactions with industry? Research Policy. 36, 1295-1313.

D'Este, P., Perkmann, M., 2010. Why do academics engage with Industry? The entrepreneurial university and individual motivations. Journal of Technology Transfer. 36, 316-339.

Dutrénit, G., Arza, V., 2010. Channels and benefits of interactions between public research organizations and industry: Comparing four Latin American countries. Science and Public Policy. 37(7), 541-553.

Dutrénit, G., De Fuentes, C., Torres, A., 2010a. Channels of interaction between public research organisations and industry and benefits for both agents: Evidence from Mexico. Science and Public Policy. 37(7), 513-526.

Dutrénit, G., Capdevielle, M., Corona, J.M., Puchet, M., Santiago, F., Vera-Cruz, A., 2010b. El sistema nacional de innovación mexicano: Estructuras, políticas, desempeño y desafíos. UAM/Textual S.A.

Eom, B-Y., Lee, K., 2009. Modes of knowledge transfer from PROs and firm performance: The case of Korea. Seoul Journal of Economics. 22(4), 499-528.

Eom, B-Y., Lee, K., 2010. Determinants of industry-academy linkages and, their impact on firm performance: The case of Korea as a latecomer in knowledge industrialization. Research Policy. 39, 625-639.

Etzkowitz, H., J., de Mello, M. C., Almeida, M., 2005. Towards 'meta-innovation' in Brazil: The evolution of the incubator and the emergence of a triple helix. Research Policy. 34(4), 411-424.

Etzkowitz, H., Leydesdorff, L., 2000. The dynamics of innovation: From national systems and 'mode 2' to a triple helix of university-industry-government relations. Research Policy. 29(2), 109-123.

Eun, J-H., 2009. China's horizontal university-industry linkage: Where from and where to? Seoul Journal of Economics. 22(4), 445-466.

Eun, J.H., Lee, K., Wu, G., 2006. Explaining the "University-run enterprises" in China: A theoretical framework for university-industry relationship in developing countries and its application to China. Research Policy. 35, 1329-1346.

Fernandes, A.C., Campello de Souza, B., Stamford da Silva, A., Suzigan, W., Chaves, C.V., Albuquerque, E., 2010. The importance of academy-industry interaction for the brazilian immature innovation system: Evidences from a comprehensive database. Science and Public Policy. 37(7), 485498. 
Fontana, R., Geuna, A., Matt, M., 2006. Factors affecting university-industry R\&D projects: The importance of searching, screening and signaling. Research Policy. 35, 309-323.

Friedman, J., Silberman, J., 2003. University technology transfer: Do incentives, management, and location matter? Journal of Technology Transfer. 28(1), 17-30.

Fritsch, M, Schwirten, C., 1999. Enterprise-university cooperation and the role of public research institutions in regional innovation systems. Industry and Innovation. 6(1), 69-83.

Giuliani, E., Arza, V., 2009. What drives the formation of 'valuable' university-industry linkages? An under-explored question in a hot policy debate. Research Policy. 38(6), 906-921.

Giuliani, E., Morrison, A., Pietrobelli, C., Rabellotti, R., 2010. Who are the researchers that are collaborating with industry? An analysis of the wine sectors in Chile, South Africa and Italy. Research Policy. 39, 748-761.

Göransson, B., Maharajh, R., Schmoch, U., 2009. New activities of universities in transfer and extension: Multiple requirements and manifold solutions. Science and Public Policy. 36(2), 157-164.

Göransson, B., Brundenius, C., 2011. Universities in Transition: The Changing Role and Challenges for Academic Institutions, IDRC/Springer: Ottawa/New York.

Hanel, P., St-Pierre, M., 2006. Industry-university collaboration by Canadian manufacturing firms. Journal of Technology Transfer. 31(4), 485-499.

Heckman, J., 1978. Dummy endogenous variables in a simultaneous equation system. Econometrica. 47, 153-161.

Intarakumnerd, P., Schiller, M., 2009. University-industry linkages in Thailand: Successes, failures and lessons learned for other developing countries. Paper presented at Globelics Conference, Mexico City, 2009.

Jain, S., George, G., Maltarich, M., 2009. Academics or entrepreneurs? Investigating role identity modification of university scientists involved in commercialization activity. Research Policy. 38(6), 922-935.

Jensen, M. B., Johnson, B., Lorenz, E., Lundvall, B.A. 2007. Forms of knowledge and modes of innovation. Research Policy. 36(5), 680-693.

Jensen, P., Rouquier, J.B., Kreimer, P., Coissant, Y., 2008. Scientist who engage with society perform better academically. Science and Public Policy. 35(7), 527-541.

Lall, S., Pietrobelli, C., 2002. Failing to Compete. Technology Development and Technology Systems in Africa, Cheltenham, Edward Elgar, UK.

Laursen, K., Salter A., 2004. Searching high and low: What types of firms use universities as a source of innovation? Research Policy. 33, 1201-1215.

Laursen, K., Reichstein, T., Salters, A., 2011. Exploring the effect of geographical proximity and university quality on university-industry collaboration in the United Kingdom. Research Policy. 45(4), 507-523.

Lee, K., Lim, C., 2001. Technological regimes, catch-up and leapfrogging: Findings from the Korean industries. Research Policy. 3, 459-483.

Lee, Y., 2000. The sustainability of university-industry research collaboration: An empirical assesment. Journal of Technology Transfer. 25, 111-133.

Lee, Y., 1996. 'Technology transfer' and the research university: A search for the boundaries of university-industry collaboration. Research Policy. 25(6), 843-863.

Leisyte, L., 2011. University commercialization policies and their implementation in the Netherlands and the United States. Science and Public Policy. 38(6), 437-448.

Lorentzen, J., 2009. Learning by firms: The black box of South Africa's innovation system. Science and Public Policy. 36(1), 33-45.

Maculan A.M., Carvalho J.M., 2009. University start-ups for breaking lock-ins of the Brazilian economy. Science and Public Policy. 36(2), 109-114. 
Mansfield, E., Lee, J.Y., 1996. The modern university: Contributor to industrial innovation and recipient of industrial R\&D support. Research Policy. 25(7), 1047-1058.

Mathews, J.A., Hu, M.C., 2007. Enhancing the role of universities in building national innovative capacity in Asia: The case of Taiwan. World Development, 35 (6), 1005-1020.

Melin, G., 2000. Pragmatism and self-organization Research collaboration on the individual level. Research Policy. 29, 31-40.

Meyer-Krahmer, F., Schmoch, U., 1998. Science-based technologies university-industry interactions in four fields. Research Policy. 27(8), 835-852.

Monjon, S., Waelbroeck, P., 2003. Assessing spillovers from universities to firms: Evidence from French firm-level data. International Journal of Industrial Organization. 21(9), 1255-1270.

Mowery, D.C., Sampat, B., 2005. Universities in National Innovation Systems, in: Fagerberg, J., Mowery, D.C., Nelson, R., (Eds.), The Oxford Handbook of Innovation. Oxford University Press, New York, pp. 209-239.

Muchie, M., Gammeltoft, P., Lundvall, B-Å., (Eds.), 2003. Putting Africa First. The Making of African Innovation Systems. Aalborg University Press, Denmark.

Narin, F., Hamilton, K., Olivastro, D., 1997. The increasing linkage between U.S. technology and public science. Research Policy. 26(3), 317-330.

Nowak, M.J., Grantham, C.E., 2000. The virtual incubator: Managing human capital in the software industry. Research Policy. 29(2), 125-134.

Orozco, J., Ruiz, K., 2010. Quality of interactions between public research organisations and firms: Lessons from Costa Rica. Science and Public Policy. 37(7), 527-540.

Pavitt, K., 1984. Sectoral patterns of technical change: Towards a taxonomy and a theory. Research Policy. 13(6), 343-373.

Perkmann, M., Walsh, K., 2007. University-industry relationships and open innovation: Towards a research agenda. International Journal of Management Reviews. 9(4), 259-280.

Perkmann, M., Walsh, K., 2009. The two faces of collaboration: Impacts of university-industry relations on public research. Industrial and Corporate Change. 18(6), 1033-1065.

Rivera-Huerta, R., Dutrénit, G., Ekboir J.M., Sampedro, J.L., Vera-Cruz, A.O., 2011. Do linkages between farmers and academic researchers influence researcher productivity? The Mexican case. Research Policy. 40, 932-942.

Rosenberg, N., Nelson, R., 1994. American universities and technical advance in industry. Research Policy. (23), 323-348.

Sa, C. M., Litwin, J., 2011. University-industry research collaborations in Canada: The role of federal policy instruments. Science and Public Policy. 38(6), 425-435.

Santoro, M., Chakrabarti, A., 2002. Firm size and technology centrality in industry-university interactions. Research Policy. 31(7), 1163-1180.

Santoro, M.D., Saparito, P.A., 2003. The firm's trust in its university partner as a key mediator in advancing knowledge and new technologies. IEEE Transactions on Engineering Management. 50(3), 362-73.

Schartinger, D., Rammer, C., Fischer, M., Frohlich, J., 2002. Knowledge interactions between universities and industry in Austria: Sectoral patterns and determinants. Research Policy. (31)3, 303-28.

Segarra-Blasco, A., Arauzo-Carod, J.M., 2008. Sources of innovation and industry-university interaction: Evidence from Spanish firms. Research Policy. 37(8) 1283-95.

Sohn, W., Kenney, M., 2007. Universities, clusters and innovation systems: The case of Seoul, Korea. World Development. 35(6), 991-1004.

Stokes, D. 1997. Pasteur's Quadrant: Basic Science and Technological Innovation. Brookings Institution Press, Washington, D.C. 
Swann, G., 2002. Innovative Businesses and the Science and Technology Base: An Analysis Using CIS3 Data Report for the Department of Trade and Industry. DTI, London, UK.

Tether, B., Tajar, A., 2008. Beyond industry-university links: Sourcing knowledge for innovation from consultants, private research organizations and the public science-base. Research Policy. 37, 10791095.

Torres, A., Dutrénit, G., Sampedro, J.L., Becerra, N., 2011. What are the factors driving universityindustry linkages in latecomer firms: Evidence from Mexico. Science and Public Policy. 38(1), 31-42.

Vedovello, C., 1997. Science parks and university-industry interaction: Geographical proximity between the agents as a driving force. Technovation. 17(9), 491-502.

Vedovello, C., 1998. Firms' R\&D activity and intensity and the university-enterprise partnerships. Technological Forecasting and Social Change. 58(3), 215-26.

Vessuri, H. (Ed.), 1998. La Investigación y Desarrollo en las Universidades de América Latina. Fondo Editorial FINTEC, Caracas.

Welsh, R., Glenna, L., Lacy, W., Biscotti, D., 2008. Close enough but not too far: Assessing the effects of university-industry research relationships and the rise of academic capitalism. Research Policy. 37, 1854-1864.

Wigren-Kristoferson, C., Gabrielsson, J., Kitagawa, F., 2011. Mind the gap and bridge the gap: Research excellence and diffusion of academic knowledge in Sweden. Science \& Public Policy. 38(6), 481-492.

Wright, M., Clarysse, B., Lockett, A., Knockaert, M., 2008. Mid-range universities' linkages with industry: Knowledge types and the role of intermediaries. Research Policy. 37(8), 1205-1223.

Zucker, L.G., Darby, M.R., Armstrong, J.S., 2002. Commercializing knowledge: University science, knowledge capture, and firm performance in biotechnology. Management Science. 48, 138-153. 